جامعة مدينة السادات

كانـــــة الـــــتربية

قسم علم النفس

فعالية برنامج قائم على التفكير الأخلافي في الحد من السلوك الخطر لاى طلبة كلية التربية

مستخلص بحث مستل من رسالة ماجستير فى تخصص الصحة النفسية

$$
\text { الباحث }
$$

ضياء الرحمن محمد السيد احمد الدولتلي

$$
\text { إثراف }
$$

أ.م. د/ عصام جمعه نصار

استاذ مساعد بقسم علم النفس

كلية التربية جامعة مدينة السادات

$r \cdot r$. 


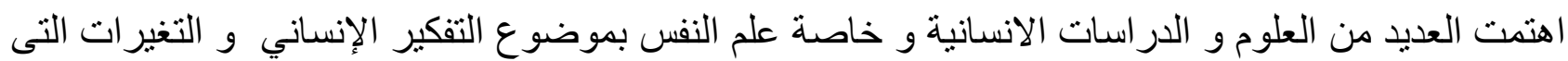

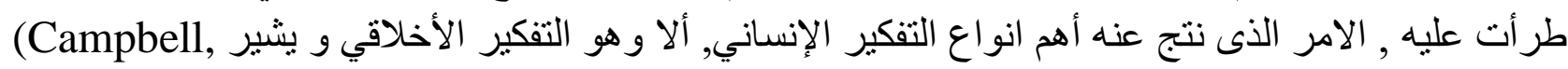

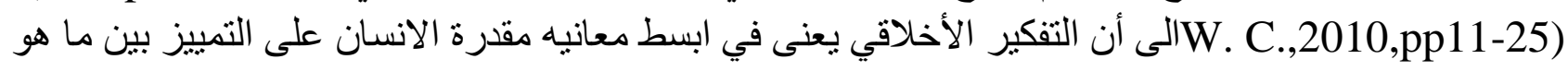

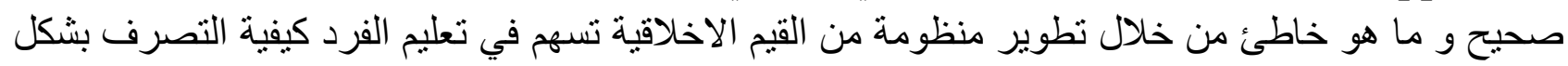

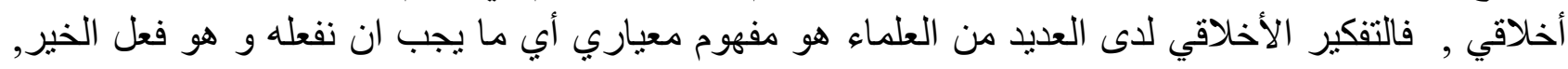

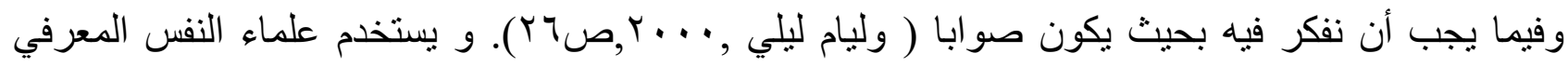

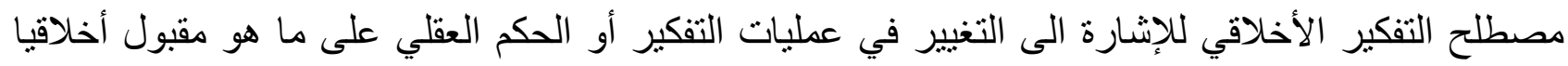

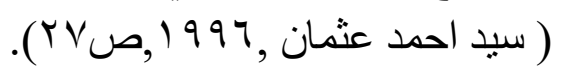

إن الافراد الذين يرتقون الى مستويات عالية من التفكير الأخلاقي اكثر ميلا لانتهاج سلوكيات معينة مثل تقديم

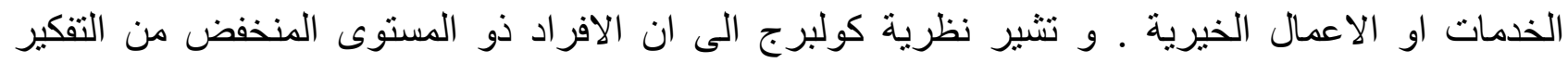

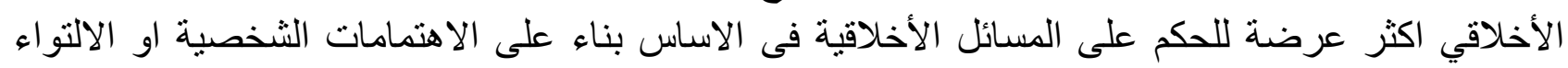

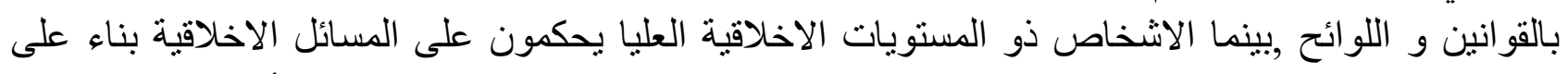

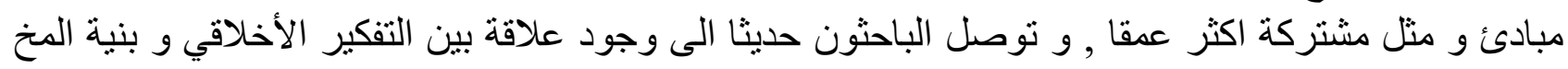

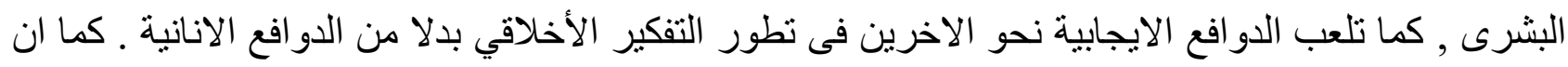

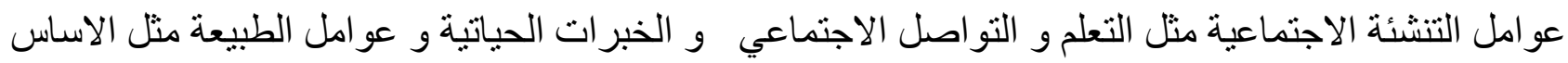

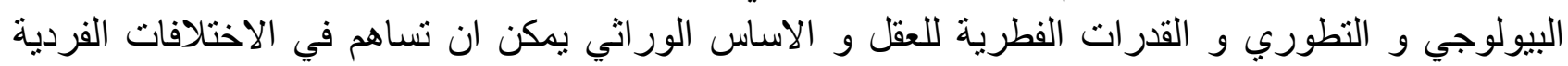

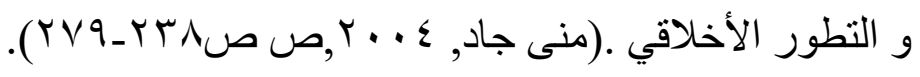

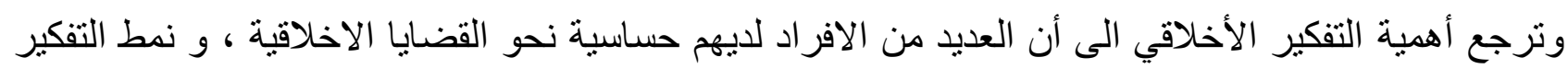

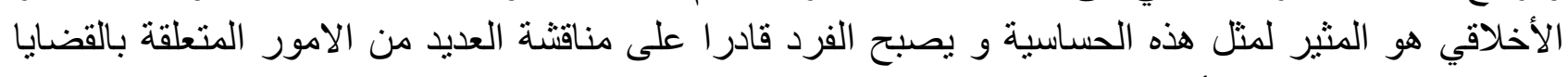

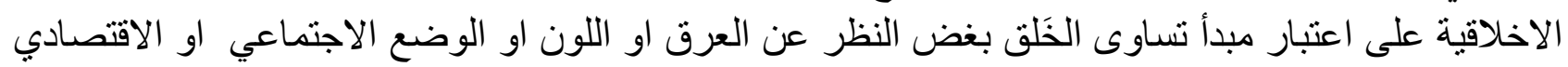
.(Liisa Myyry,2003,p.35)

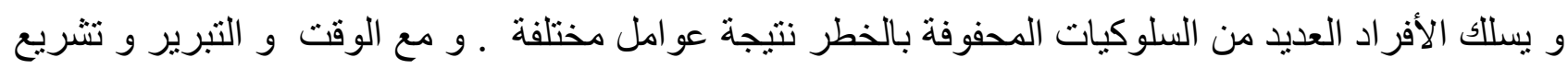

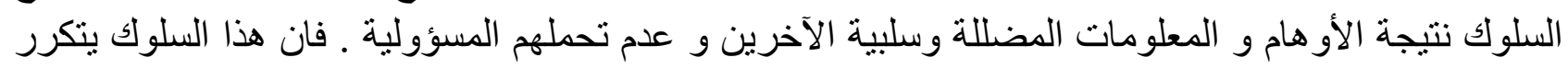

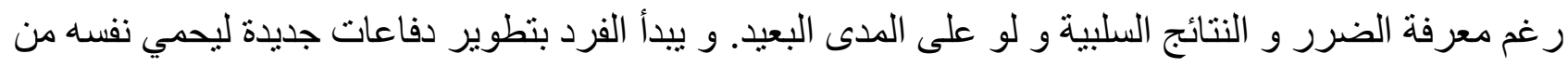

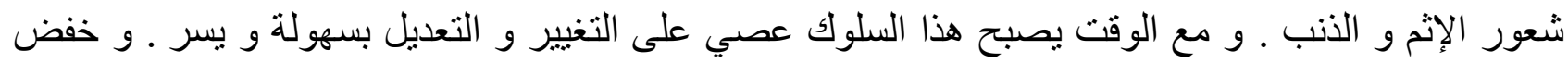

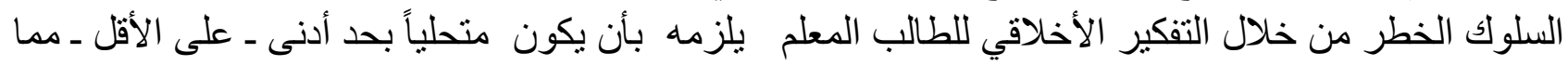

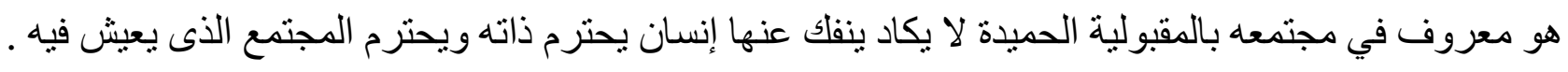

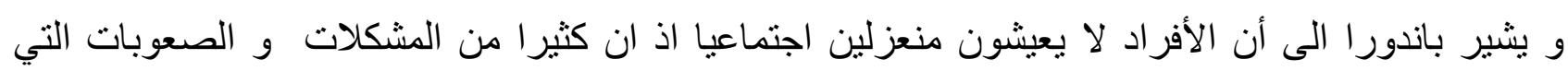

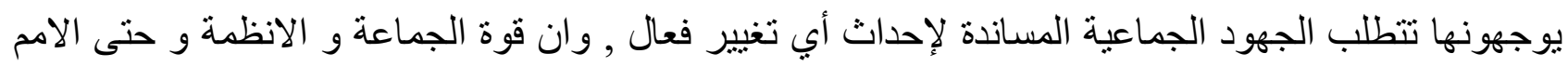

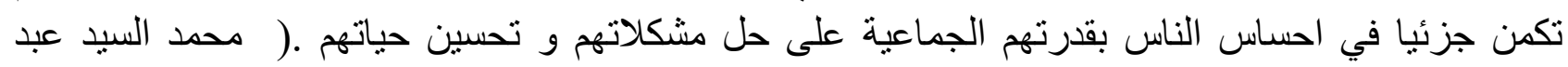

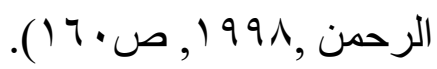


و ان ادر الك الافر اد لفعاليتهم الجمعية تؤثر فيما يقبلون على عمله كجماعات و مقدار الجهد الذى يبذلونه و قوتهم

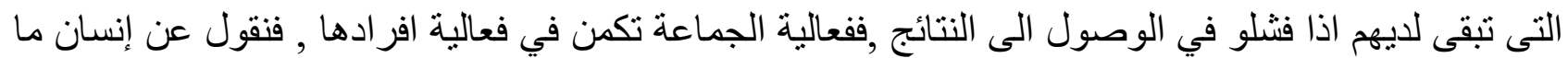

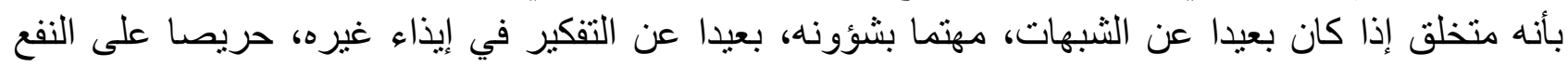

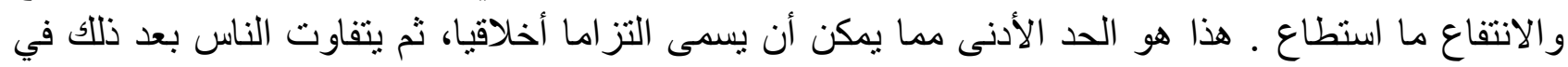

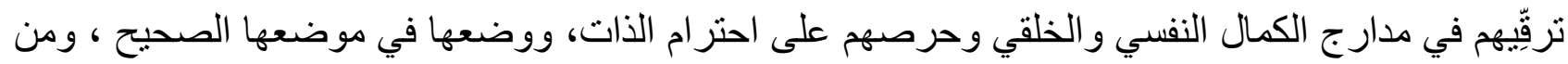

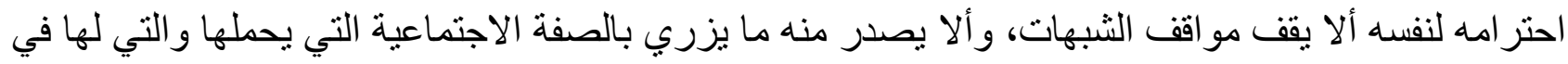
نفوس الناس قداستها و اعتبار ها، فلا يمارس سلوكيات تحمل خطورة عليه او على المحيطين به. ( نبيه إبراهيم

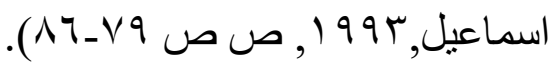

و لأهمية تتمية مستويات التفكير الأخلاقي لاى طلبة كلية التربية باعتبار هم معلمين المستقبل لإكسابهم المهار ات الحياتية اللازمة ليكونوا قادرين على مو اجهة تحديات مهنتهم , و بم سينقله من ثقافة و اثر موروث سو اءك كان لأبنائه او ابناء مدرسته. كما يفرض ضلية عليه أيضا تقديس النظام الجامعي، واحتر ام التنظيمات العلمية المعدول بها،

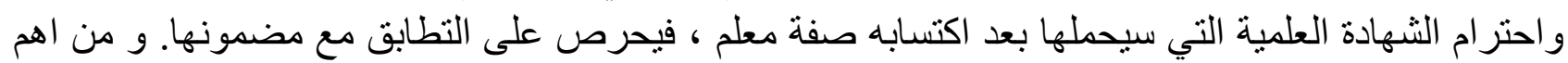

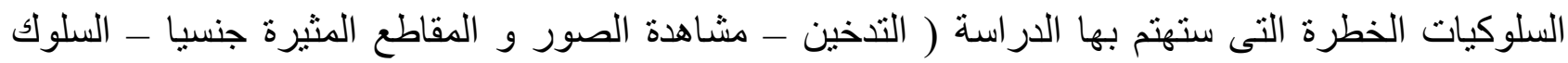

\section{مشكلة الاراسة}

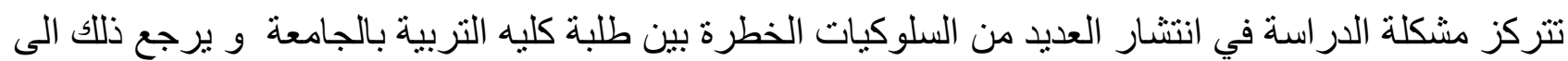
افتقار العديد من الطلبة الى الاساليب المناسبة لعملية التفكير الأخلاقي في الحد من السلوك الخطر, و بالتحديد

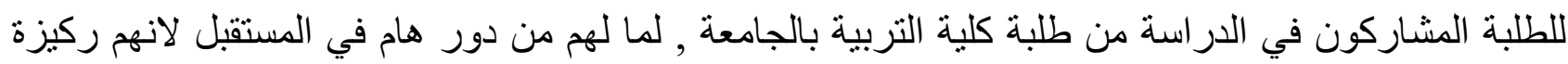

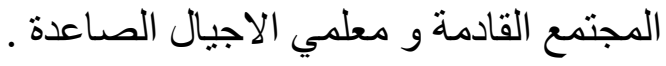

و قد تلاحظ زيادة في مستويات بعض السلوكيات الخطرة و ازدياد معدلات تكرارها , لذلك وجب الاهتمام بالأساليب و الاستر اتيجيات اللازمة لإحداث امر فارق في تقليل تأثثير معدلات الخطورة الناجمة عن السلوكيات

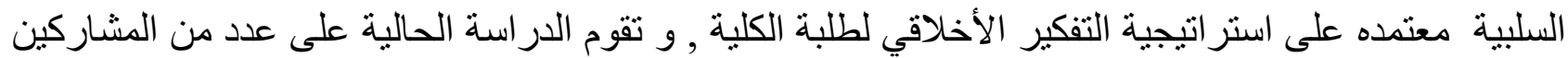

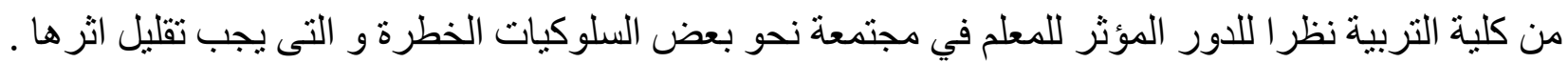

و كما يذكر هانتز و رايت ان الطالب الذي يتمتع بالمسئولية الاجتماعية و التفكير الأخلاقي يعطى مؤشرا عما

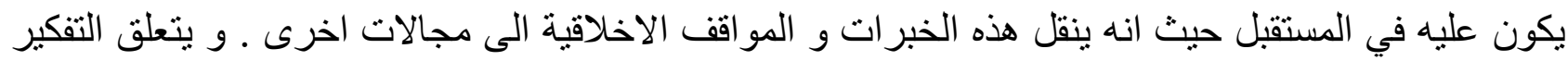
الأخلافي بالطريقة التي يصل بها الفرد الى حكم معين سواء بالصو اب او الخطاء على مواقف اخلاقية ,و قيميه

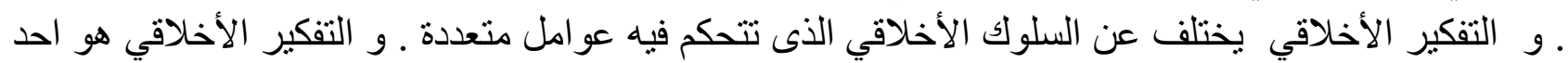

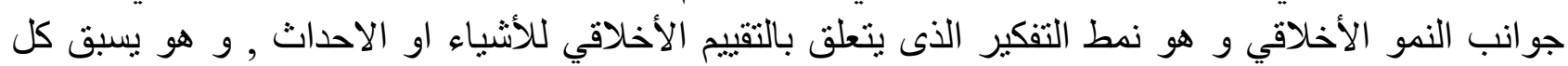

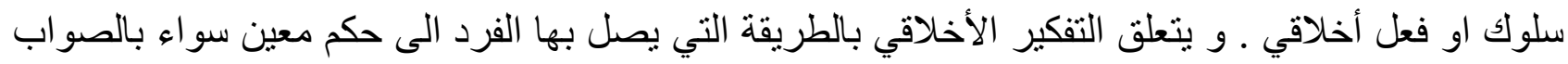
او الخطاء, اما السلوك الأخلاقي فهو سلوك معقد يتضمن بداخله عناصر متعددة ,و التفكير الأخلاقي ما هو الا هذه العناصر, فالنمو الأخلاقي يؤدى الى التفكير الأخلاقي ويقود الاخير بدوره الى السلوك الأخلاقي ( عادل 


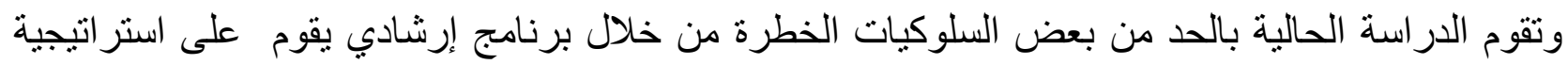

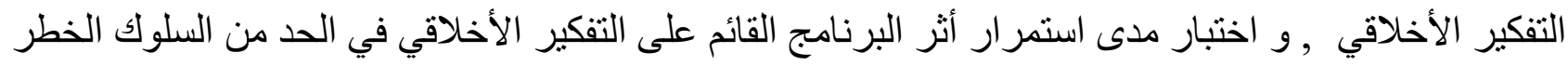

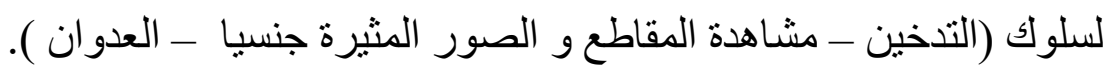
و تتبلور مشكلة الدراسة في التساؤلات الاتية : ا ـ ما مدى فعالية برنامج إرشادي قائم على التفكير الأخلافي فى الحد من السلوك الخطر لدى عينه من طلبة

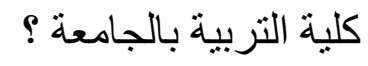
ז- هل سيقل السلوك الخطر لطلبة كلية التربية ( المشاركون )بعد تعرضهم لبرنامج قائم على التفكير الأخلاقي

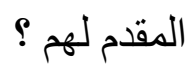
זـ هل هناك استمرارية لأثر البرنامج الارشادي فى الحد من السلوك الخطر لطلبة كلية التربية (المشاركون)

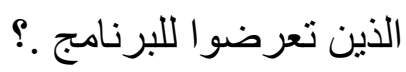

\section{أهداف الدراسة}

يعد التفكير الأخلافي جوهر الحياة الاخلاقية لدى طالب كلية التربية لما يكسبه للطالب من ادر الك للقو اعد الاخلاقية

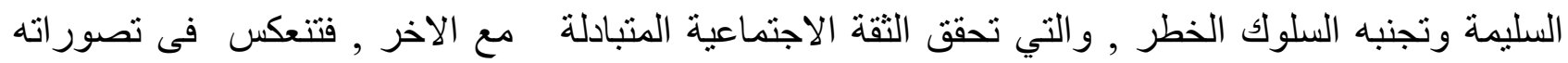

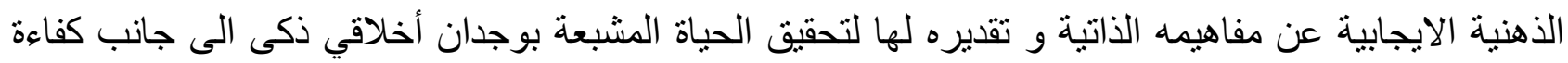

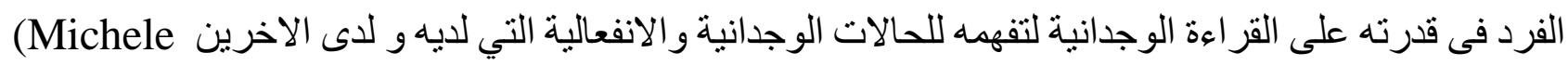
Borba,2001p.12)

1 - التعرف على انماط السلوك الخطر بين طلبة كلية التربية. r- خلق مرجعية تعتمد على التفكير الأخلافي لطلبة كلية التربية للحد من السلوك الخطر . r- الحد من سلوك ( التدخين - مشاهدة الصور و المقاطع الاباحية - العدوان ). ـ ـ التحقق من فعالية برنامج إرشادي قائم على التفكير الأخلاقي فى الحد من السلوك الخطر لدى مجموعة

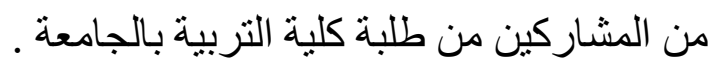

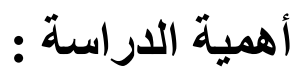

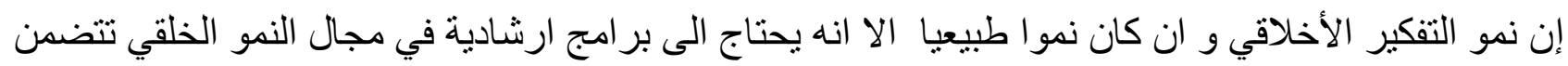

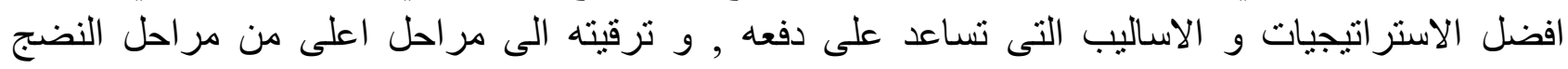

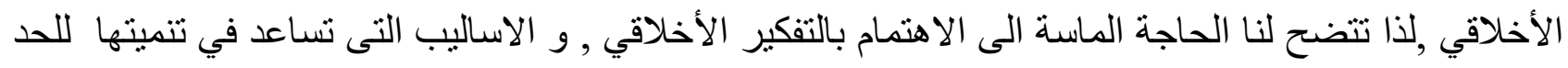

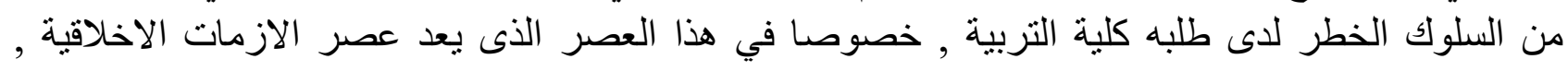

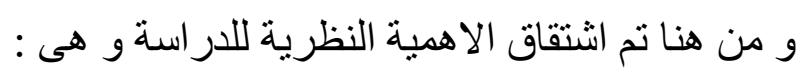




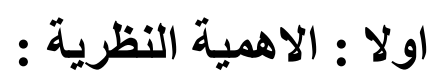

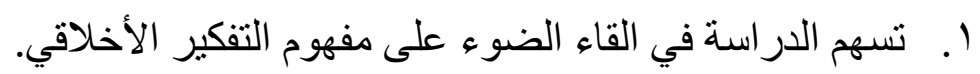

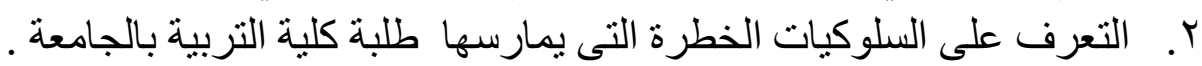
r. تهتم بشريحة هامة في المجتمع وهم شباب كليه التربية لانهم ركيزة المجتمع القادمة و معلمي الاجيال

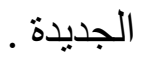

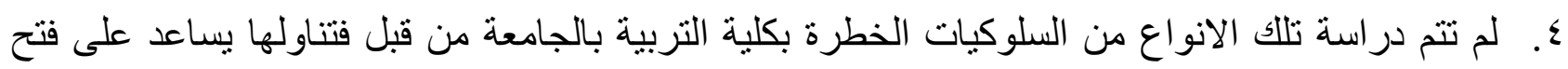

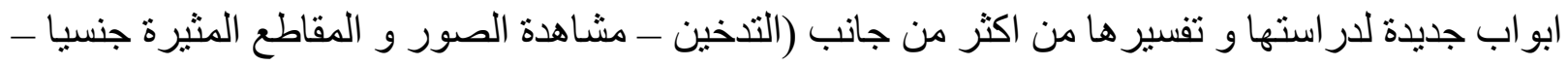

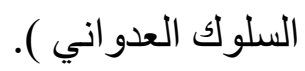
•. خلق مرجعية فكرية أخلاقية لاى طلبة كلية التربية للحد من ممارسات بعض السلوكيات المهددة و الخطرة: .

\section{ثنانيا : الاهمية التطبيقية :}

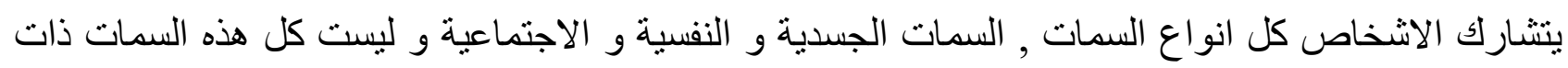

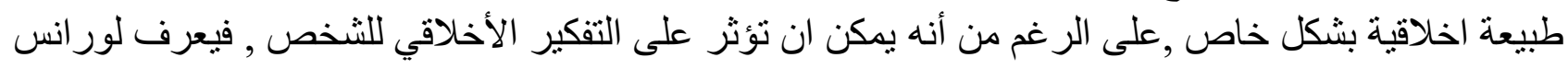

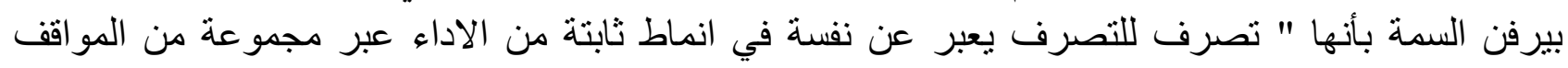

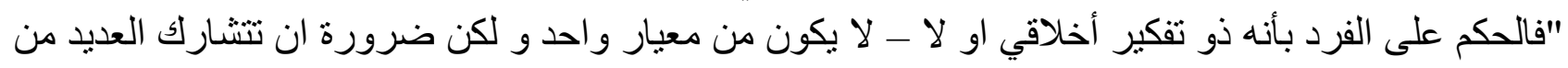

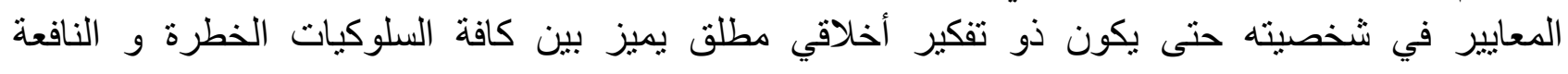

.(Pervin,L.,1994,pp.103-113)

و يقوم العديد من الافر اد بعض السلوكيات الخطرة مثل التذخين و تتناول المخدرات و سوء التغذية و ادمان

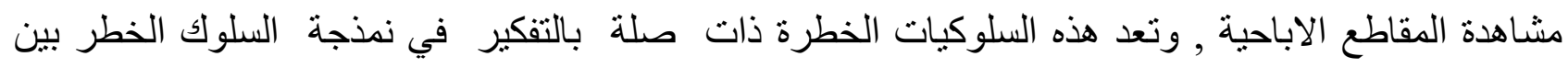

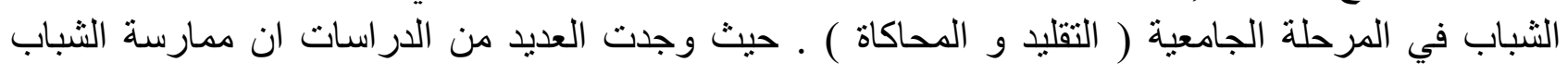
الهصريين لسلوكيات الخطر هي من الاسباب الاساسية للوفاة(

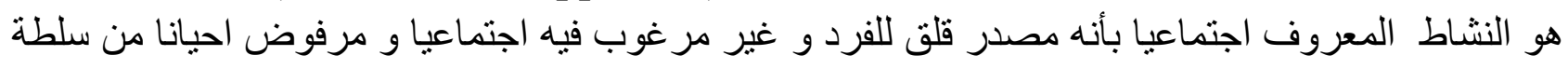

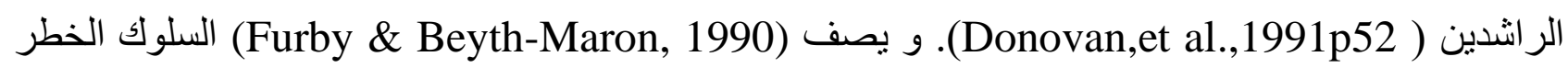

بأنه السلوك الذى ينطوي على امكانية حدوث خسارة ذانية (Igra and Irwin ,1996 p35).

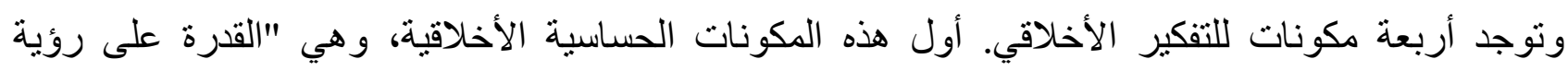

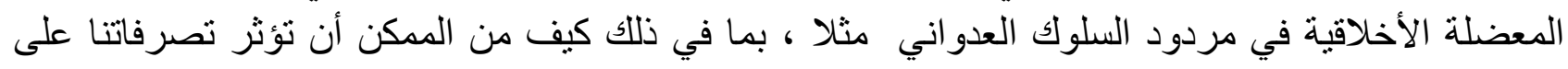

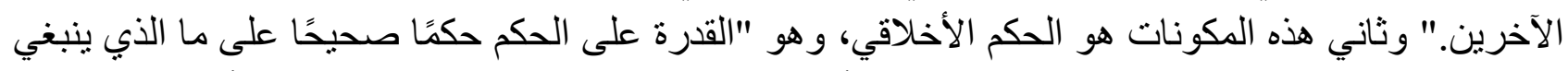

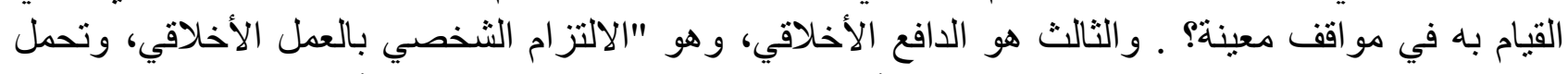

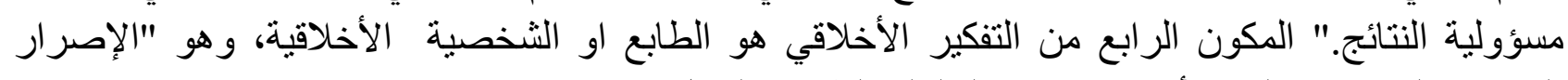

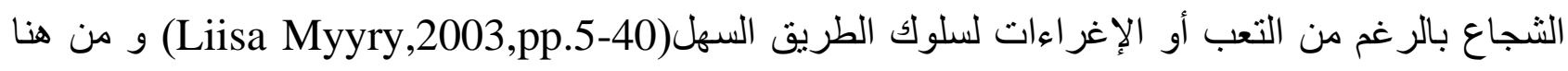
اشتقت الاهمية التطبيقية للار اسة كالتالي : . 
1 ا ت تسهم الدراسة بتفعيل ألية التفكير الأخلاقي لطلبة كلية التربية .

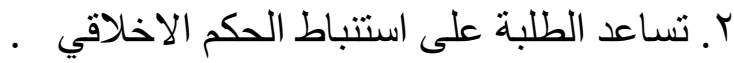

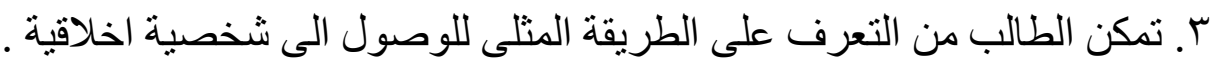

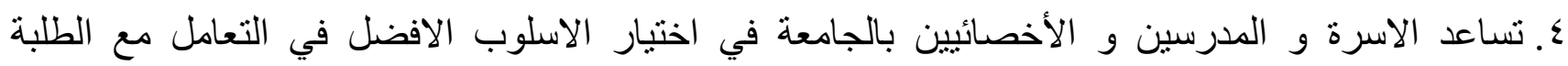

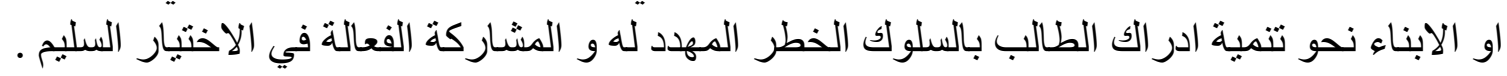

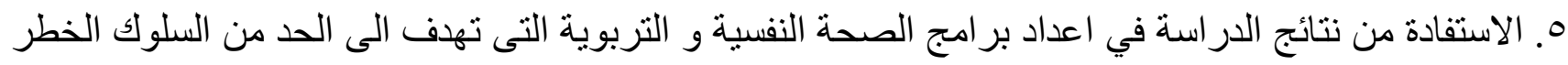

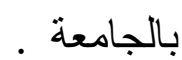
T. بناء مقياس لقياس السلوك الخطر لطلبة الجامعة .

محددات الدراسة : م

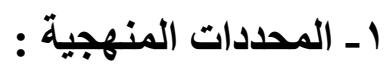

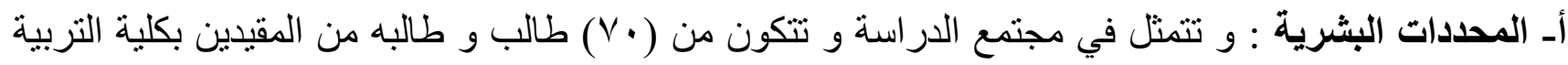

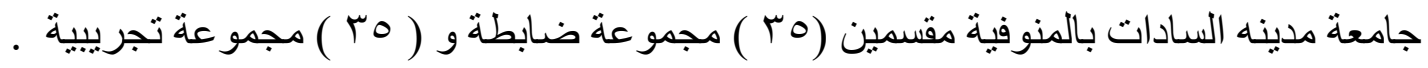
بـ منهج الدراسة :استخدام المنهج التجريبي و ذلك لملائمة طبيعة عينة الدراسة .

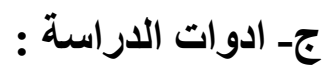
1. مقياس السلوك الخطر و يتضمن ثلاث ابعاد و هى ( سلوك التدخين - سلوك مشاهدة الصور و المقاطع

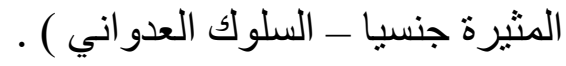
r البرنامج الإرشادي للحد من السلوك الخطر لطلبة كلية التربية (مجتمع الدراسة ). و هو برنامج قائم على التفكير الأخلافي للحد من السلوك الخطر ( التنخين - مشاهدة الصور و الدقاطع المثيرة

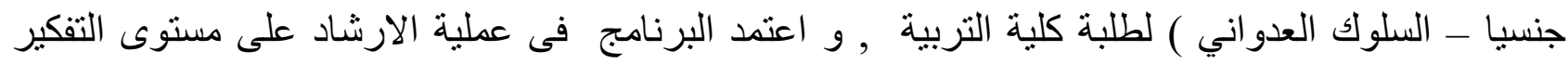

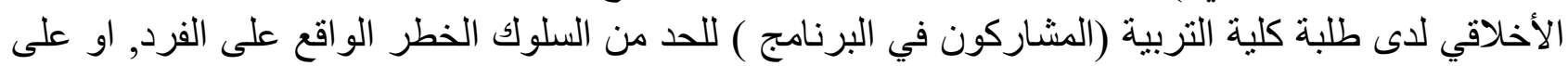

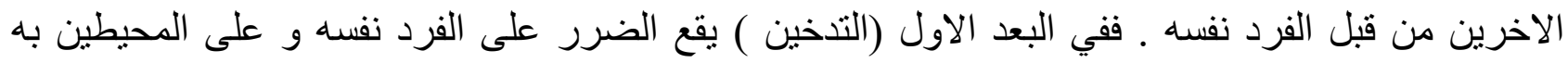

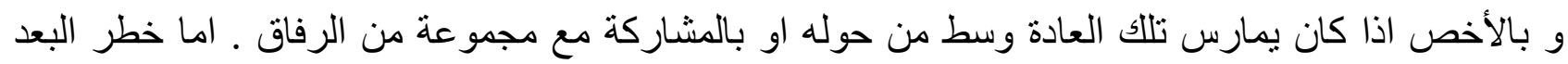

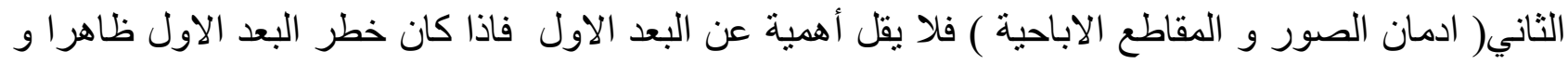

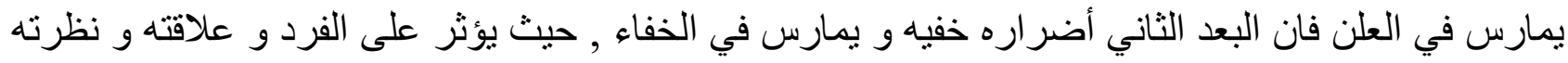

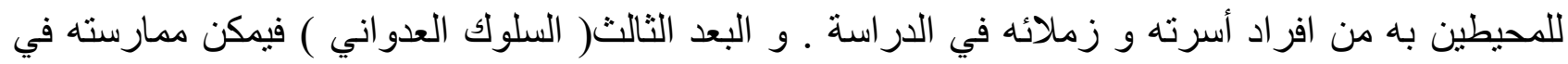

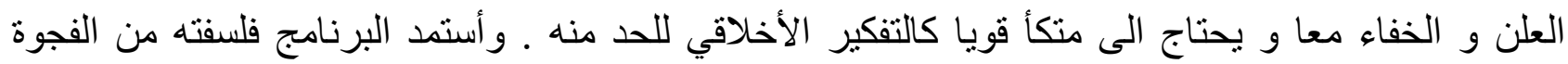

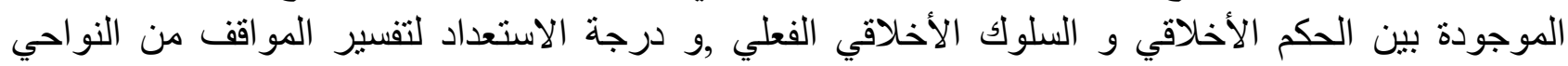

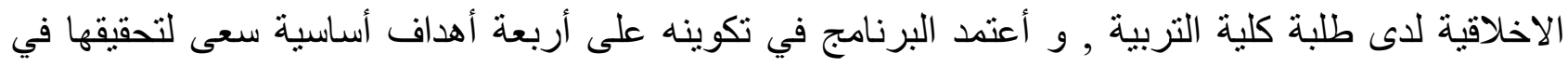

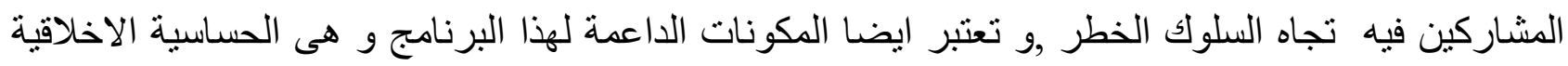

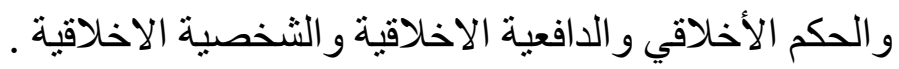




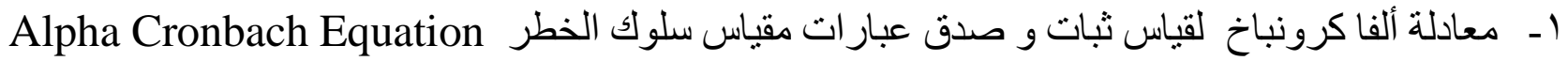

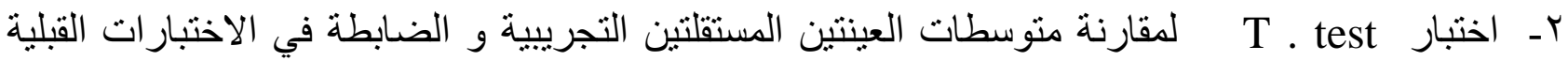
و البعدية Independent Sample Test.

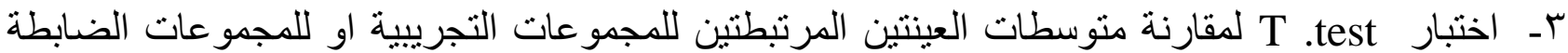
.Paired Sample Test عـ - معادلة كو هين Cohen's d لقياس حجم الأثر للعينات المرتبطة .

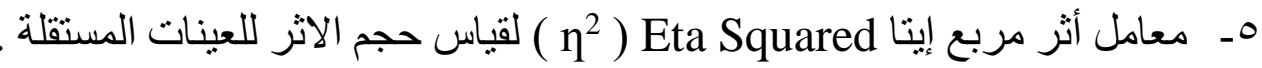

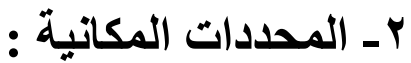

كلية التربية - جامعة مدينة السادات - محافظة المنوفية

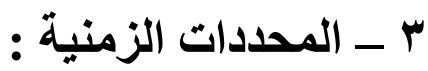

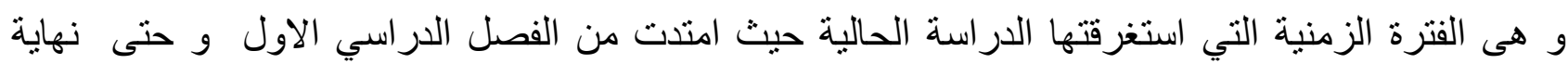

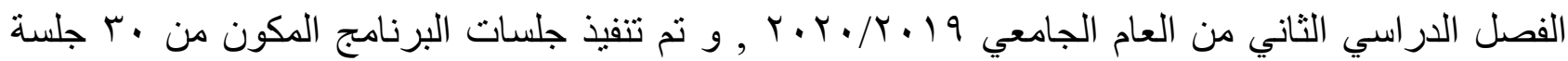

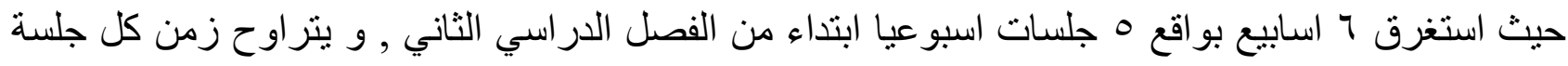
.

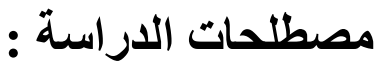

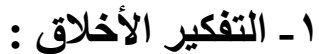

- يثير التفكير الأخلاقي الى طبيعة القرارات الاخلاقية و ما يرتبط بها من مبررات عقلية لما هو مقبول

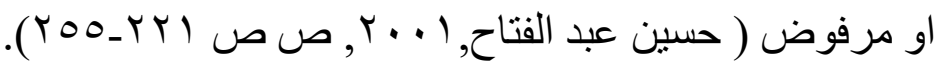

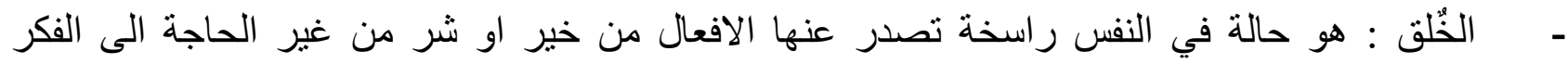

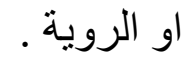

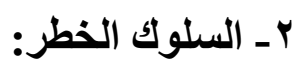

ـ ـ السلوك اصطلاحا هو اعمال الانسان الارادية المتجه نحو غاية معينه مقصودة تهدف الى تحقيق مطالب

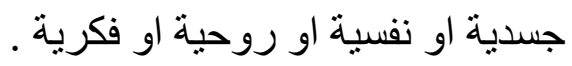
- ـ و يشير (Hallahan\&Kuffman,1988,165) بأنه السلوك الذى يصل الى التطرف (المبالغة ) فهو ليس مجرد سلوك يختلف عن المعتاد و لكنه مشكلة لا نختفى بسرعة ركما انه سلوك غير مقبول بالنسبة للتوقعات

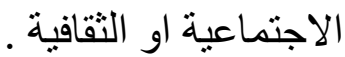

و يعرف السلوك الخطر اجرائيا بأنه الفعل الذى يقوم به الفرد و يسبب اذى نفسى او جسدي له او لغيرة

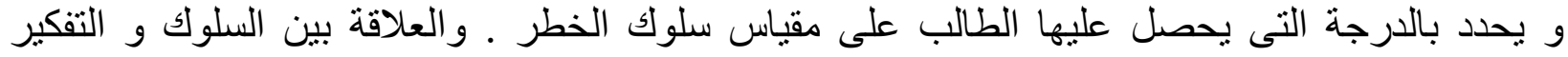
الاخلاقي هى علاقة الدال بالمدلول او الاثر بالمؤثر . 


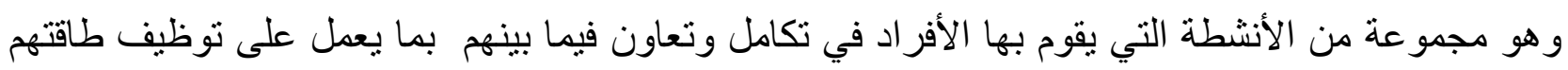
و إمكانياتهم فيما يتعلق مع ميولهم وحاجاتهم وقدر اتهم و استعدادهم في جو يسون يسوده الأمن و والطمأنينة.

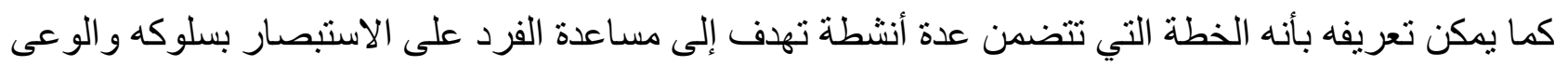

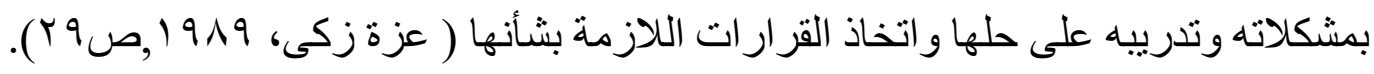

كـ فعالية :

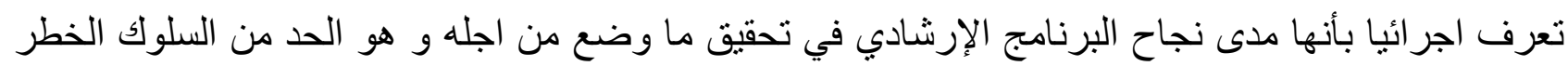

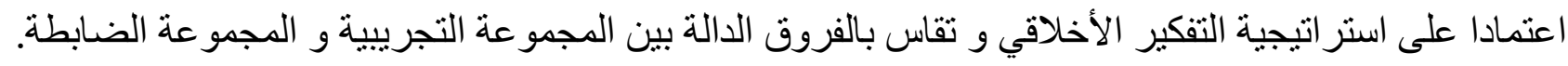
و تعرف الفعالية بانها القدرة على تحقيق النتيجة المقصودة طبقا لمعايير محددة مسبقاو التى يتم تصميم البرنامج

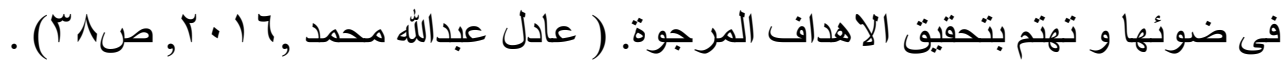

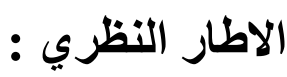

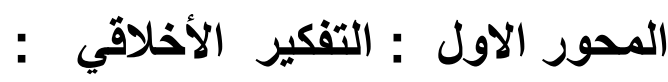

تستخدم الصفة (الأخلافي او الخلقي ) بمعنين رئيسيين فى الكتابات النفسية :

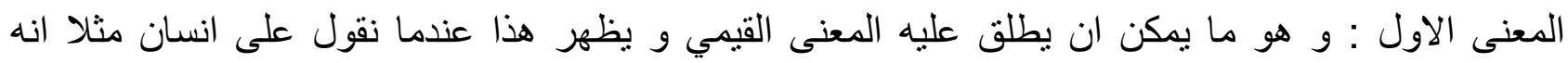

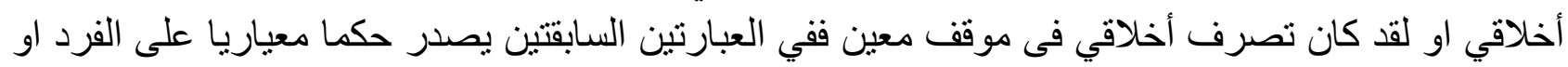

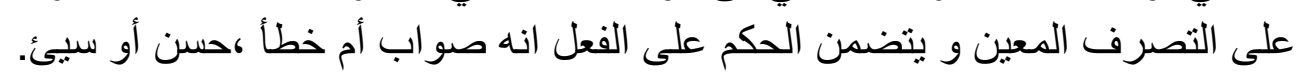
المعنى الثاني : و يطلق عليه الاستخدام الوصفي و يكون هو المقصود عندما يقال مثلا "ان هذه المشكلة مشكلة

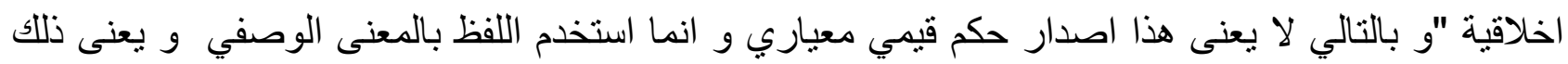

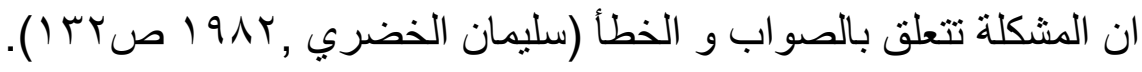

و تهتم الدارسة الحالية بالتفكير الأخلافي بالمعنى الوصفي من حيث مواجه الفرد خلال مر احل عمره للمشكلات

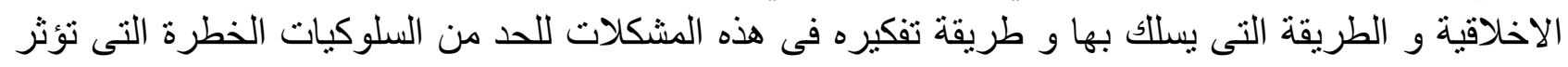

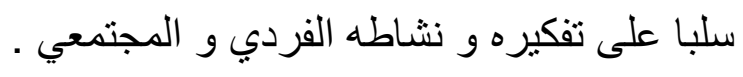

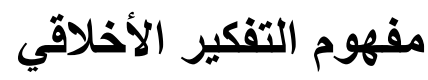

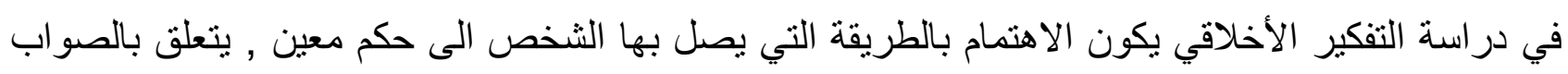

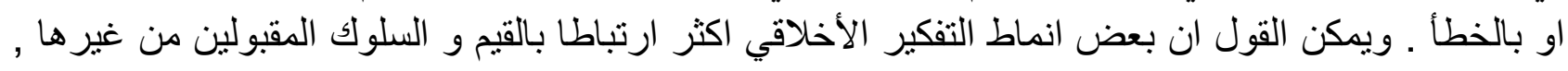

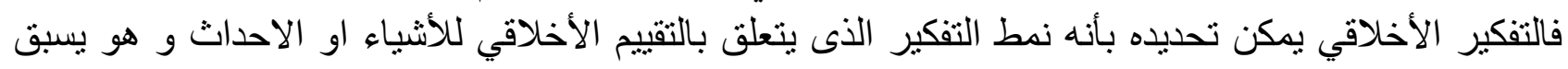

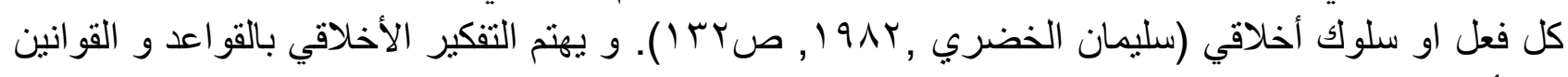

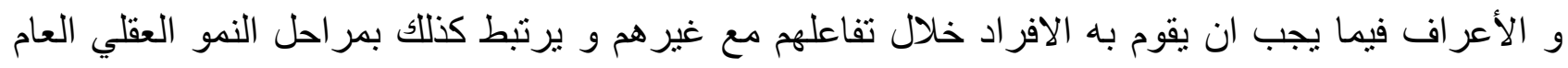

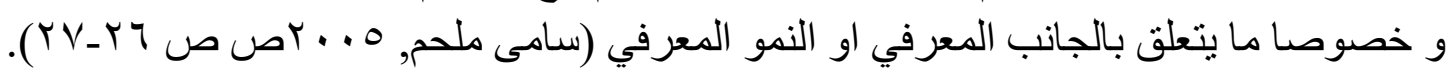


و يسير التفكير الأخلاقي بشكل تتابعي بمعنى أن الانتقال من مرحلة اخلاقية الى اخرى يتم بشكل تتابعي ، فكل

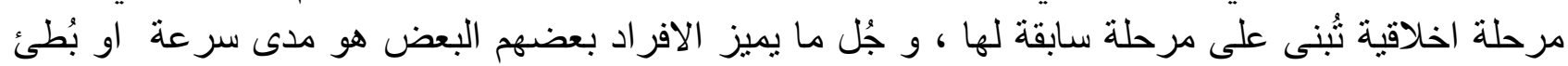

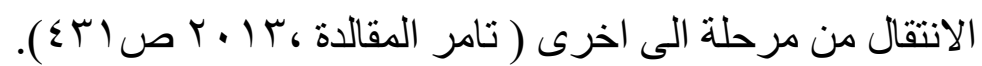

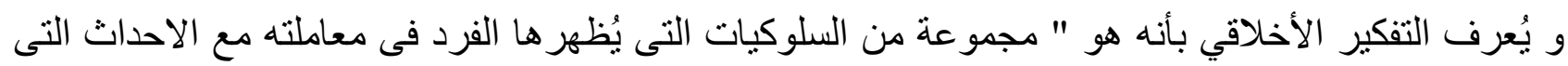

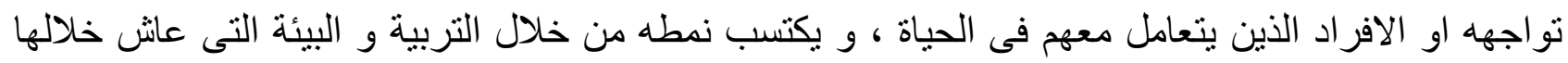

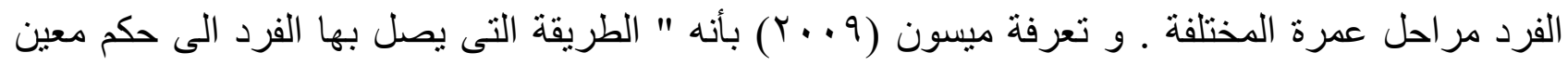

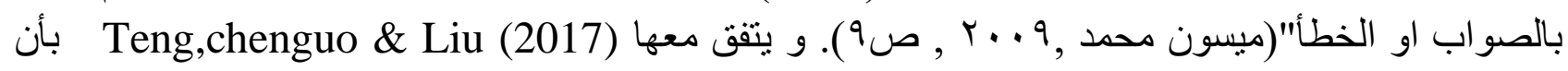
التفكير الأخلاقي هو القرار الذى يتوصل اليه الفرد عند مواجهه مشكله متعلقة بالصواب او الخطأ .(Teng,chenguo \& Liu,2017,p54)

و يعرفه Staber\&Yang (2015) بأنه وصف و تقييم وتبرير ما ينعلق بالعمل الصحيح و السلوك المقبول

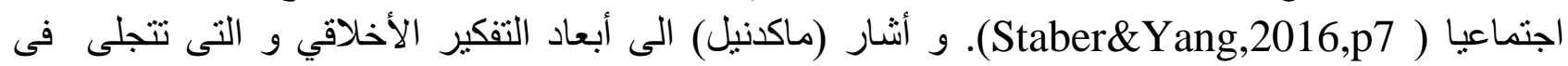

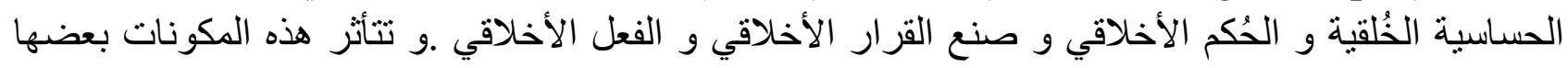

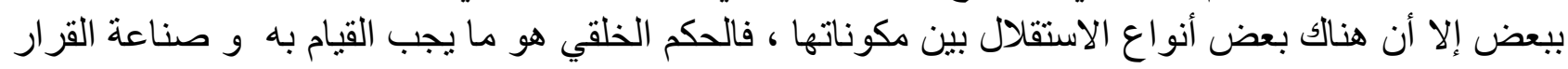

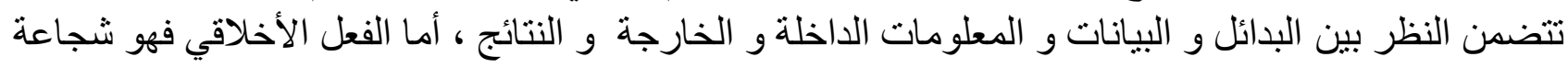
الفرد فى تتفيذ ما قرره سابقا (McDaniel,A.,K.,1998).

\section{اهمية التفكير الأخلاقي :}

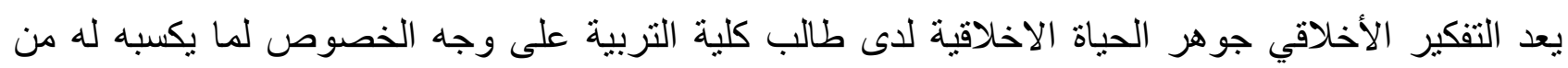

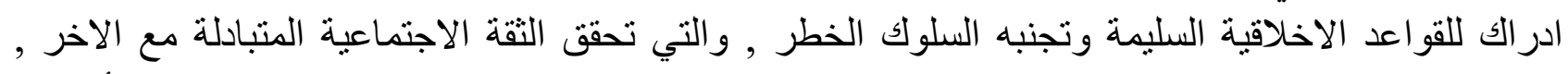

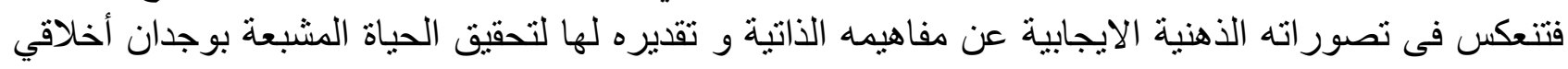

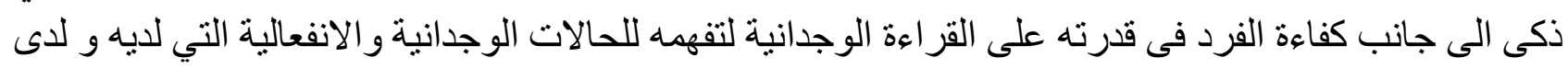
الاخرين (Michele Borba,2001p.12).

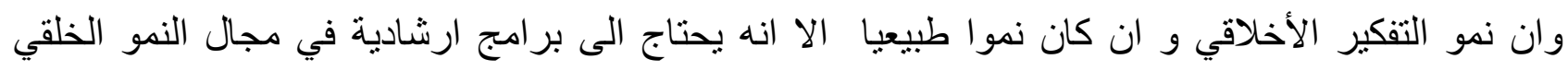

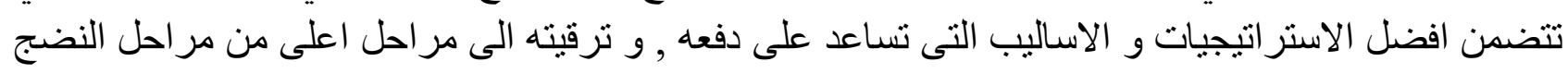

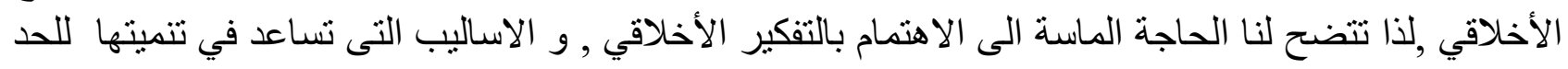

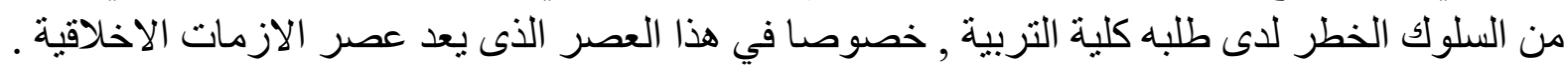

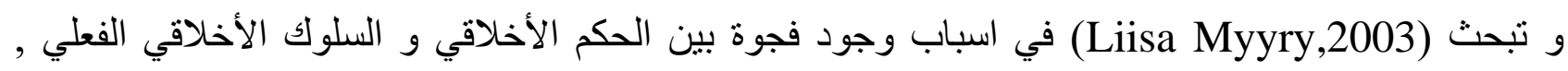

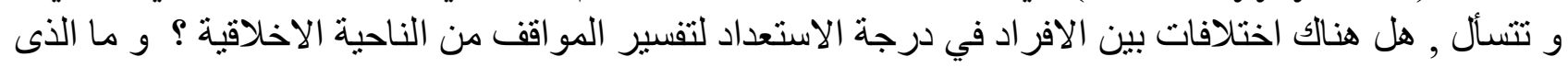

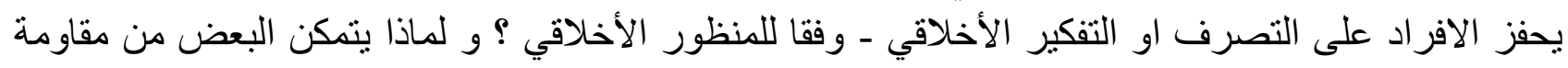

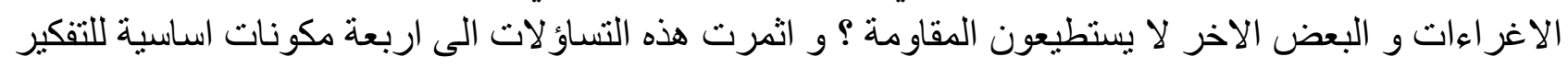
الأخلاقي (Liisa Myyry,2003,pp.5-40) و هیى: 


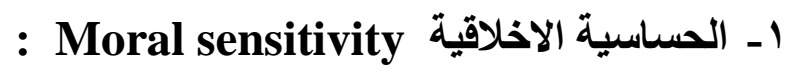

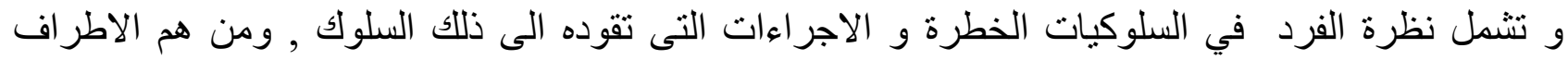

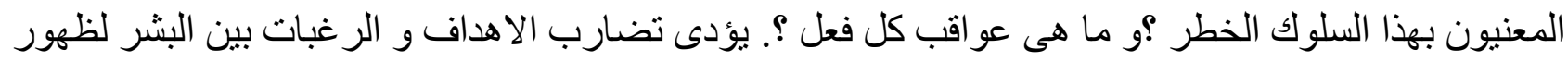

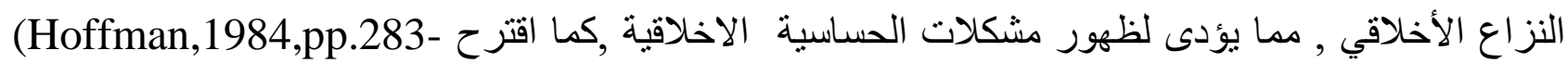

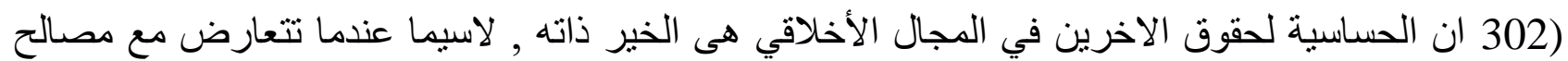

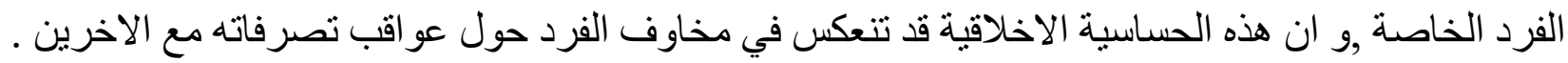
يتفق معه (Rest,1994,pp.1-26)حول قضية الحساسية الاخلاقية بأنها الوعى لكيفية تأثير اعمالنا على الألى الأني

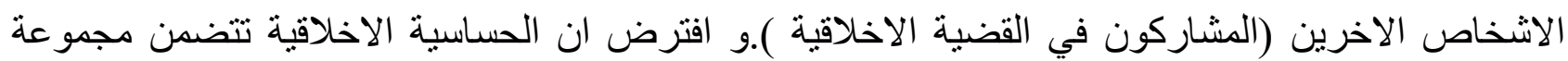

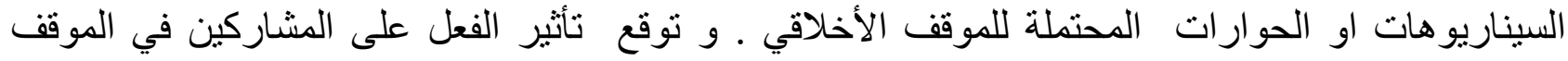

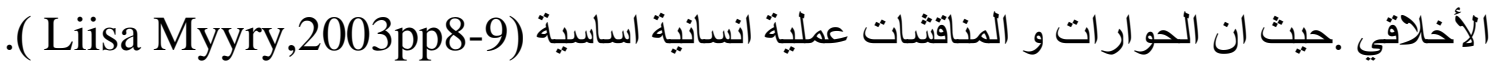

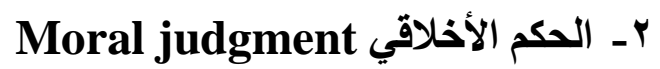

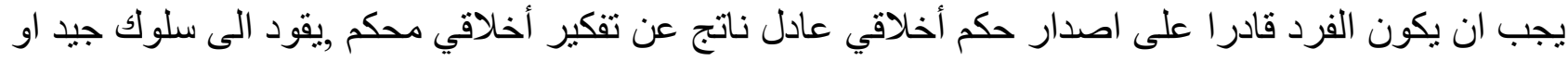
مقبول اجتماعيا, او على اقل درجة الا يمثل خطورة على الفرد نلف نلفه او غيرة من المنو اجدين في حدود بيئته الخارجية (Liisa Myyry,2003,p.6).

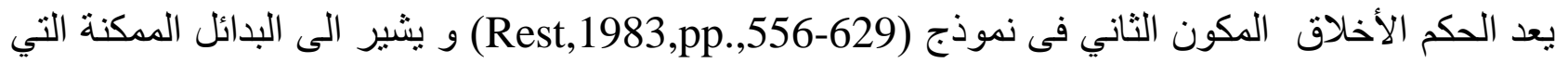

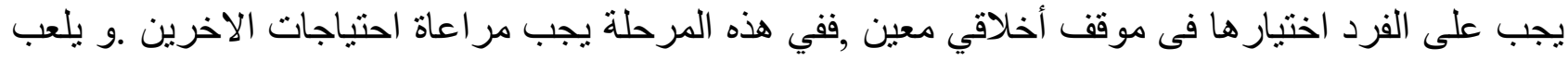

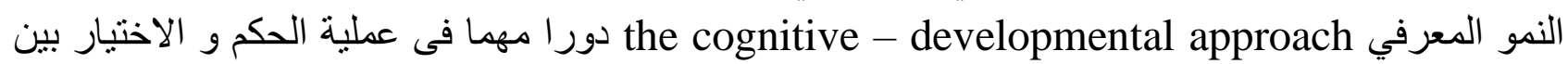

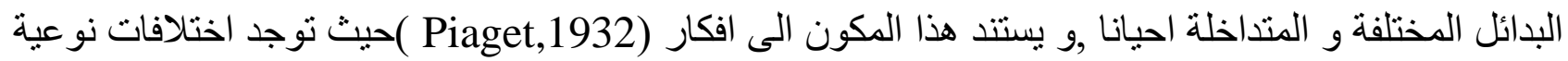

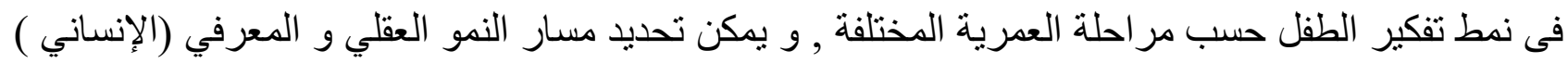

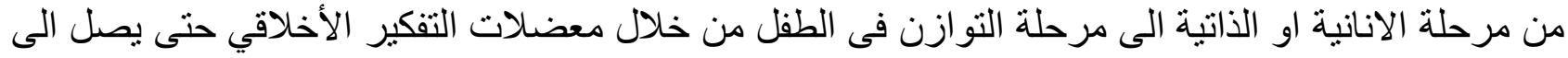

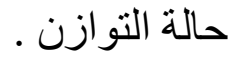

\section{Moral motivation بـ الدافعية الأخلاقية}

عرف (Rest,1986) الدافعية الأخلافية بأنها كل ما يتعلق بقيمة الفرد ,و بطريقة اخرى هى مقدار ما يعطى الألفي

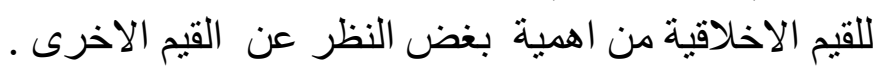

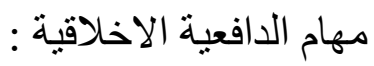

• الوصول الى نتائج تنافسية ذات قيمة مثلى يمكن تطبيقها .

تحدد المسار الأخلاقي للفعل المر اد القيام به .

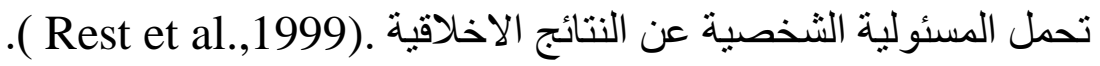

ارتباط الدافع بالهوية الثخصية و مفهوم الدور ( Liisa Myyry,2003,p.26 ).

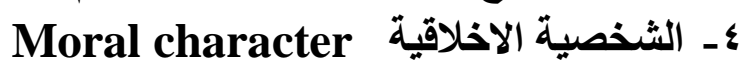

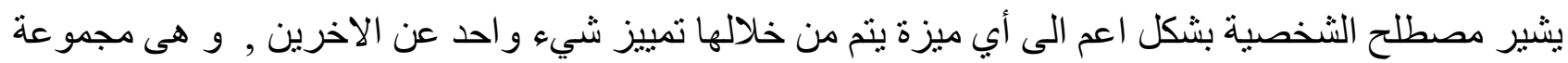

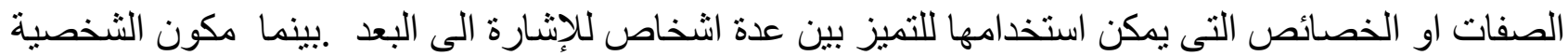


Liisa الاخلاقية ينطوي على الثجاعة و القدرة على تنفيذ المهارات و العمل تحت أي ضغط او تهديد .( Myyry,2003,p.6)

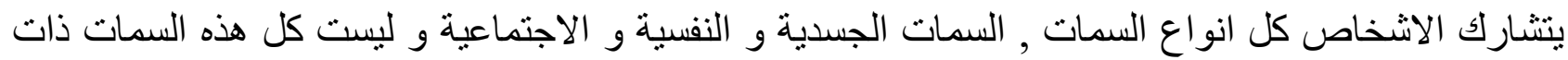

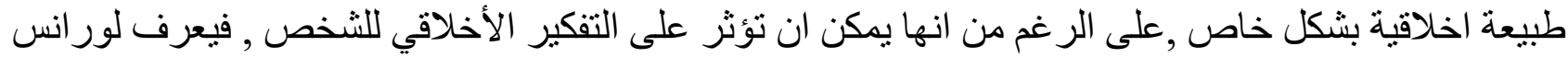

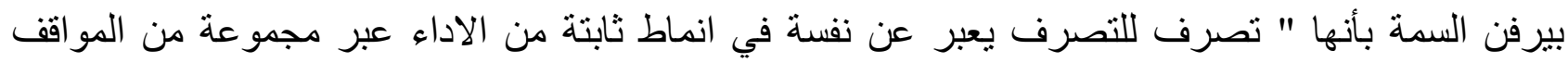

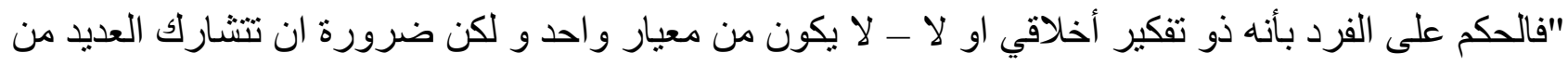

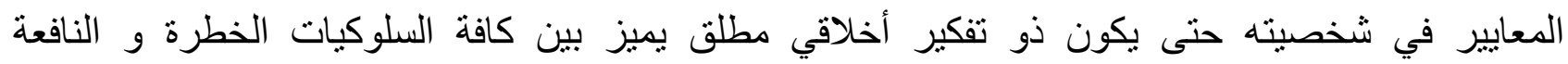

.(Pervin,L.,1994,pp.103-113)

وفقا لنظرية كولبرج فإن التتابع في نمو التفكير الأخلاقي هو ثابت وموحد في جميع التئه الثقافات ويمناز التفكير

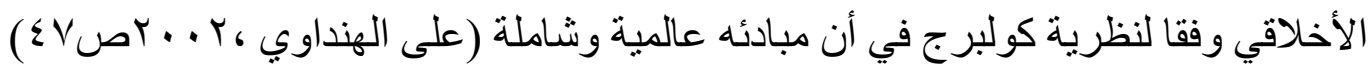

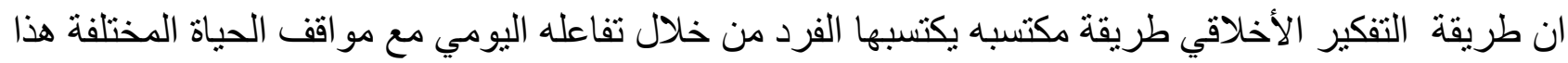

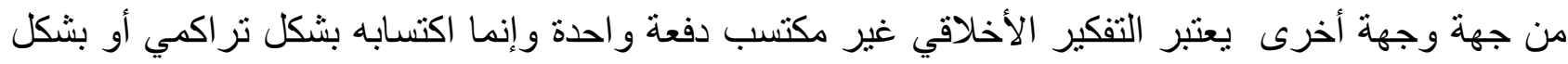

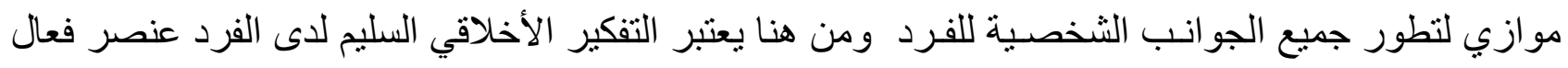

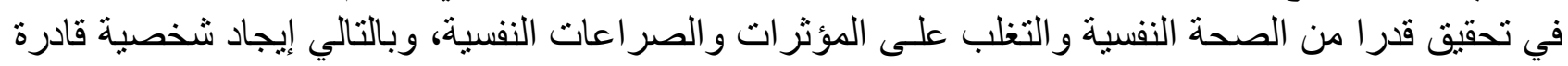

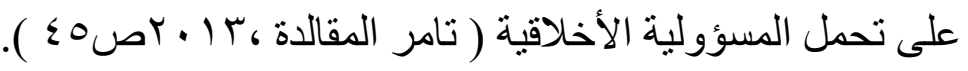

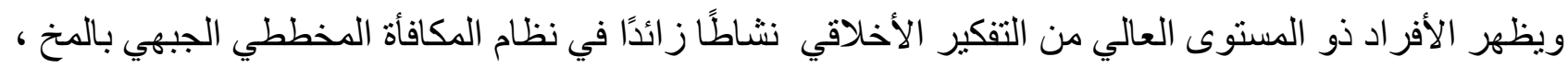

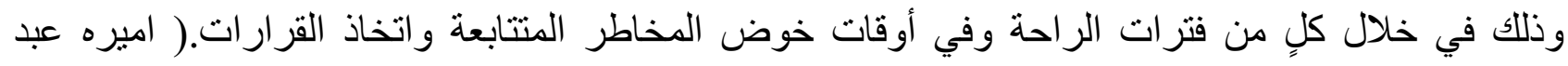

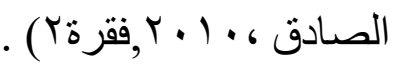

\section{النظريات المفسرة للتفكير الأخلاقي ( اولا : النظريات الايناميكية )}

-

افترض فرويد ان شخصية الفرد تتكون من ثلاث مكونات الهو و الاناو الانا الاعلى و تلعب هذه المكونات

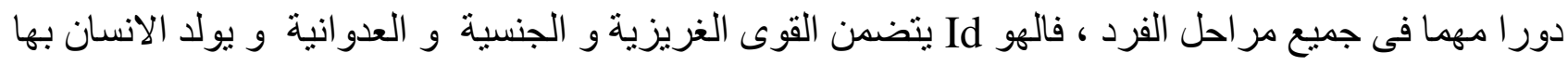

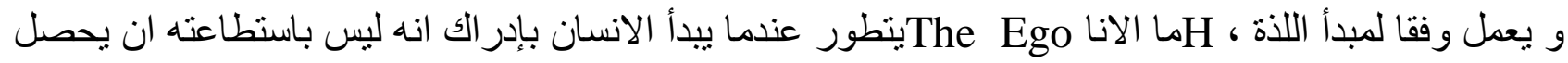

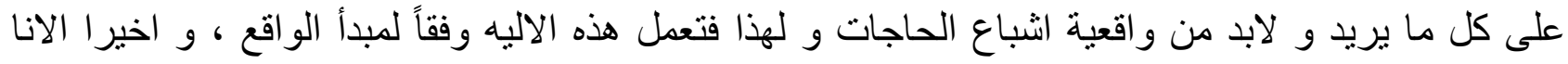

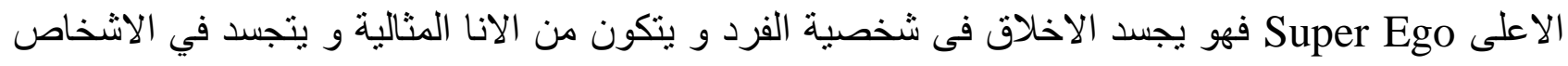

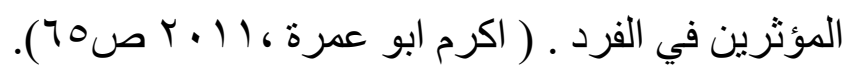




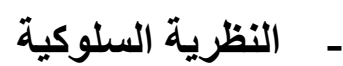

يرى السلوكيين ان انواع السلوك مثل التقليد و الثواب و العقاب و التعزيز و الانطفاء و غير ها من شتى انواع التول

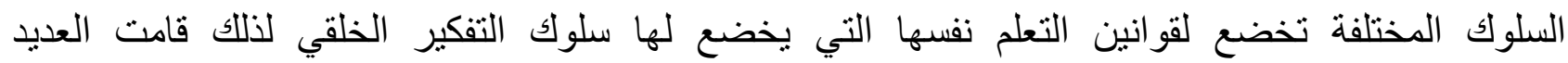
من الدراسات على الاخلاق كسلوك و ليس كتفكير او تبرير (Greif,E.B.,1981 p.223).

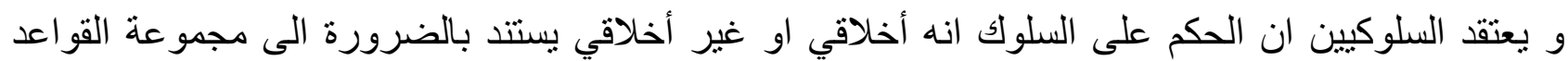

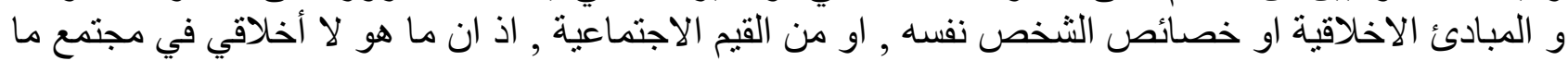

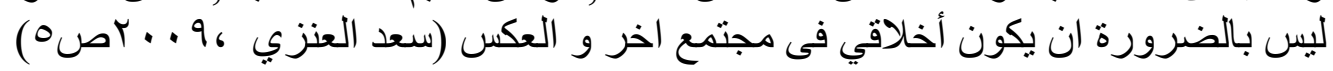

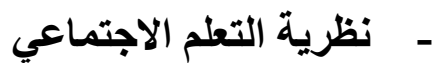

تركز هذه النظرية على أهية التفاعل الاجتماعي والمعايير الاجتماعية والسياق والظروف الاجنماعية

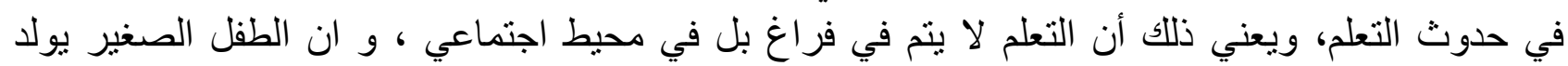

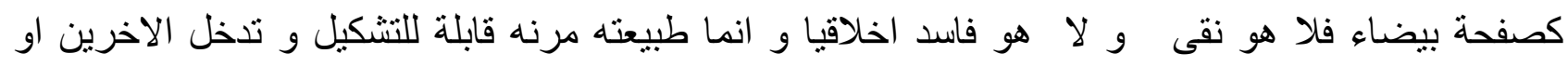

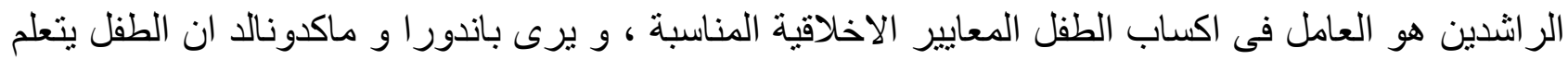

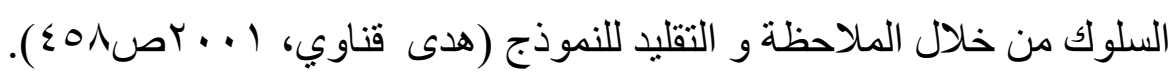

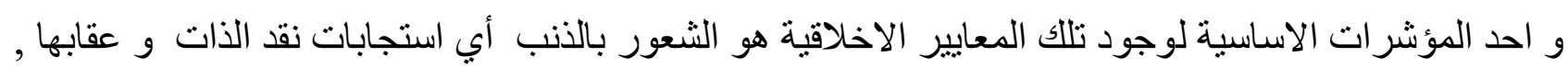

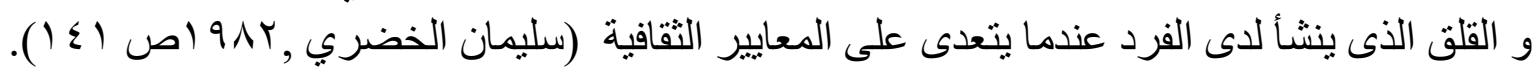

\section{ثنانيا : النظريات النمائية}

\section{ا ـ نظرية بياجيه في النمو الخلقي :}

لقد ميز بياجيه بين اربع مر احل رئيسية يمر بها تفكير الطفل : الطفل منذ ولادته حتى اكتمال نضجه العقلي .

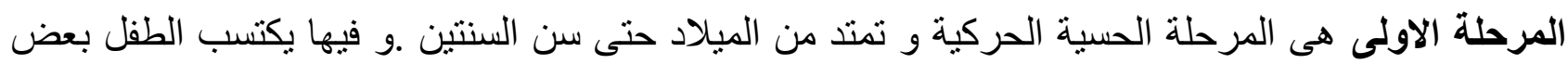

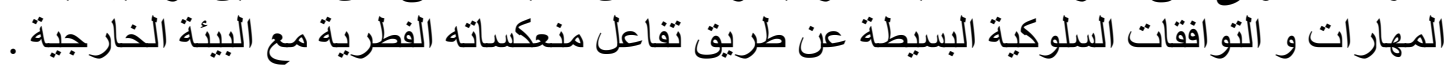

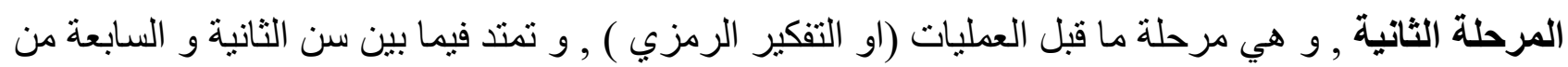

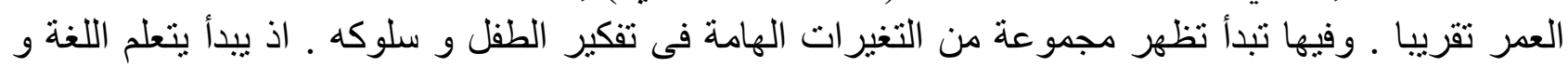

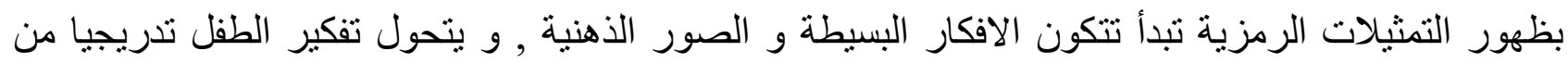

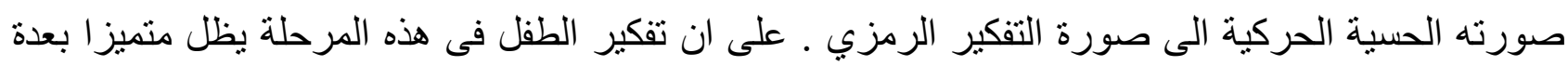

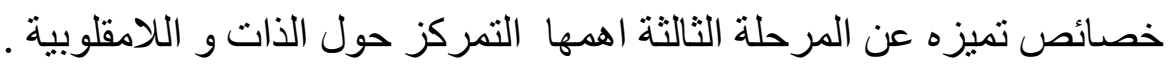

اما المرحلة الثالثة فهي مرحلة العمليات المحسوسة , تمتد من سن السابعة حتى الحادية عشر تقريبا ـوفيرها يبدأ

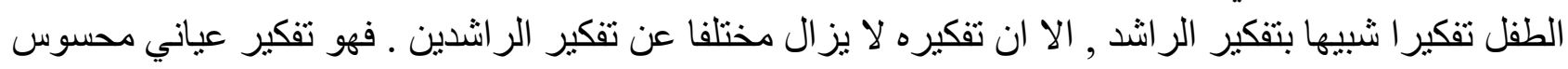

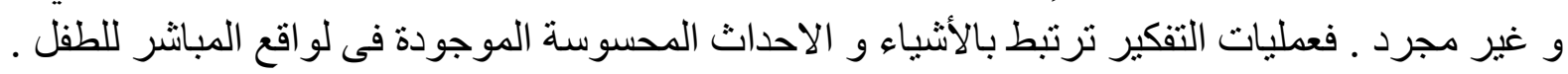

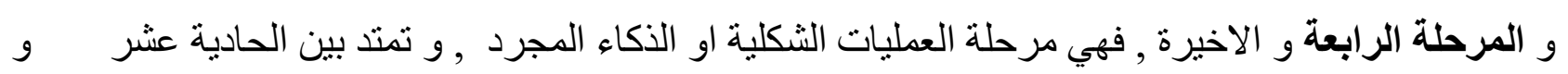

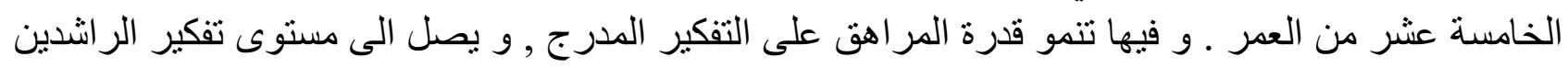

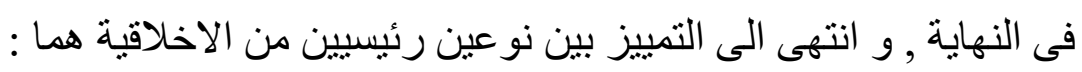




\section{1- الاخلاقية خارجية المنشأ : Heteronomous Morality با ب- الاخلاقية داخلية المنشأ : Autonomous Morality}

\section{r بـ نظرية بك و هافجهرست عن الاخلاقية :}

افترض بك و هافجهرست بناء على دراساتهما وجود خمسة انماط من الخلق , و تصور التتابعها مع نمو الفرد

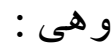

1 إلـياد الأخلاقي في الطقولة Amoral in Infancy

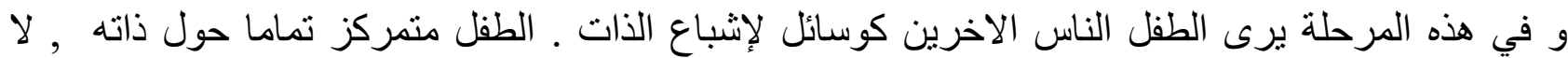

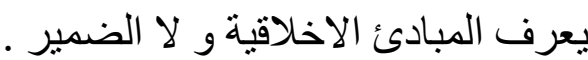

r-الوسيلية في الطفولة المبكرة Expedient in early childhood:

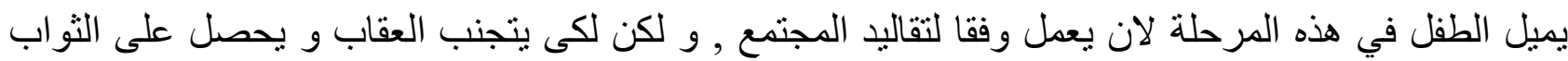

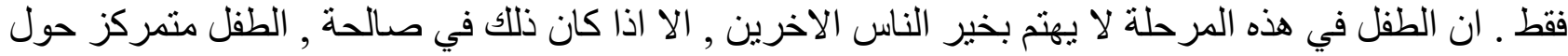

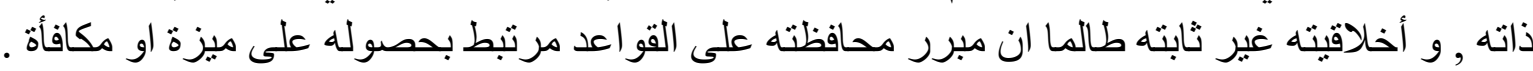

r- أ ـ المجاراة في الطقولة المتأخرة : Conformity in later childhood:

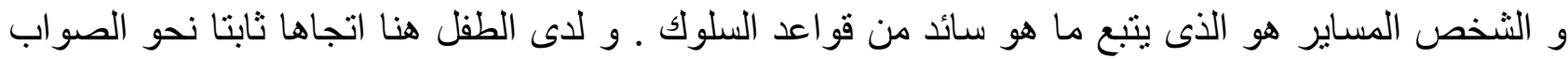

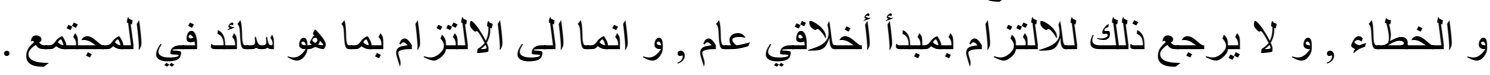

rاب - الضمير اللاعقلاني في الطفولة المتأخرة Irrational conscientious:

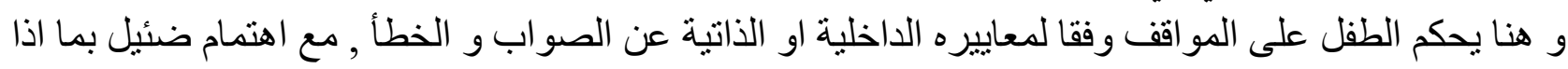

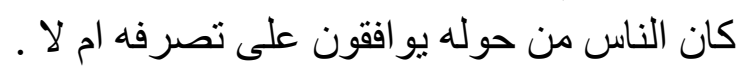

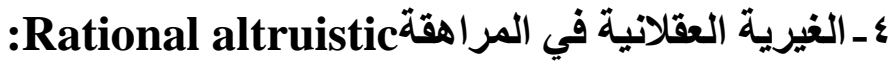

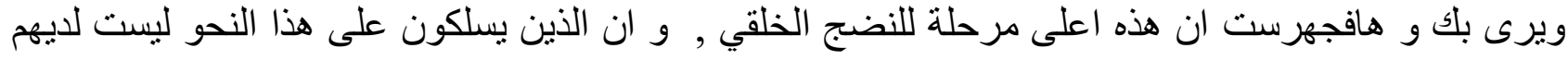

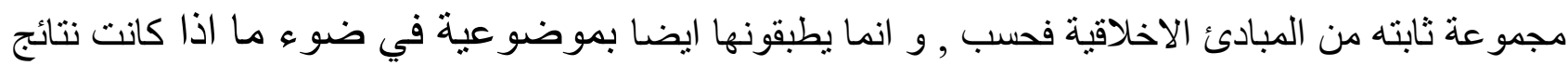

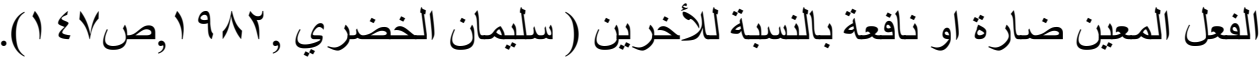

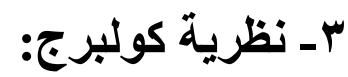

تعتبر نظرية لورنس كولبرج Lawrence kohlberg أحدث نظريات النمو الخلقي ونمو التفكير الخلقي بشكل

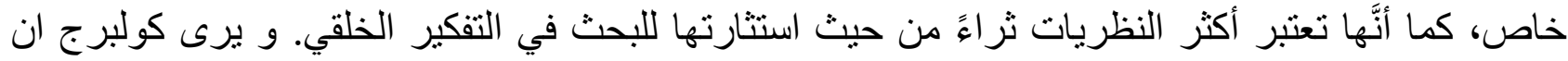

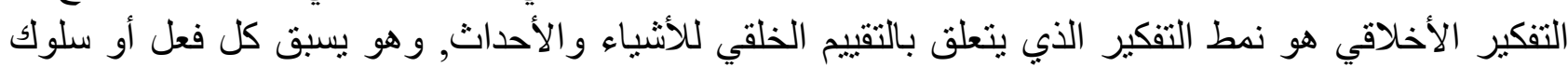

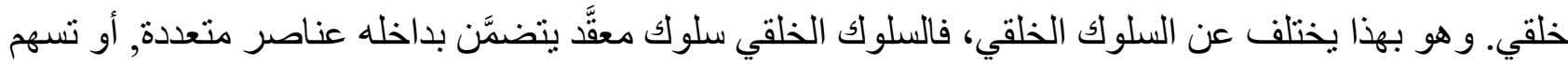

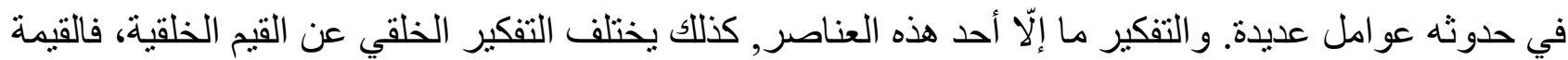

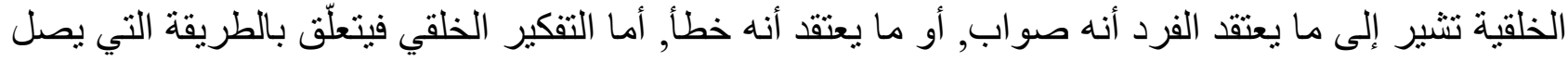

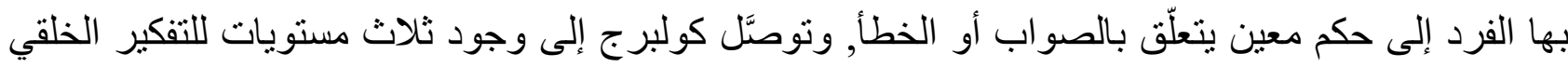
هي (المستوى قبل التقليدي و المستوى التقليدي و المستوى بعد التقليدي). 
المحور الثاني : السلوك الخطر DANGERES BEHAVIOR

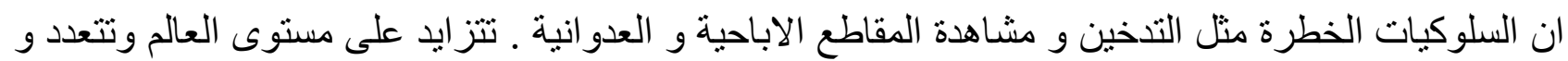

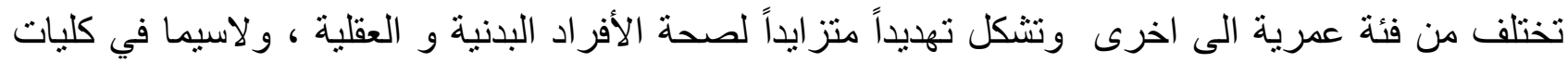

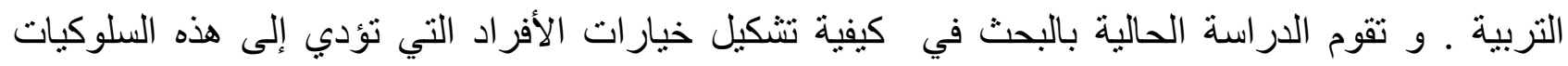

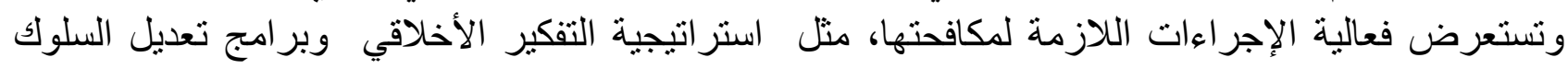
الخطر .

\section{The Definition Of Dangers Behavior تعريف السلوك الخطر}

on the grounds for " لأول مرة في كتابات فرويد (190) Danger في مقالة بعنوان مفهوم الخطر detecting a particular syndrome form neurasthenia under the description anxiety "neurosis

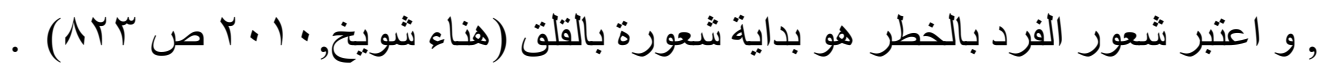

و يعرف الخطر لغويا بأنه " حالة من التعرض للضرر او الالم او الفقدان او الاصابة او الثر " (ويكيبيديا ,

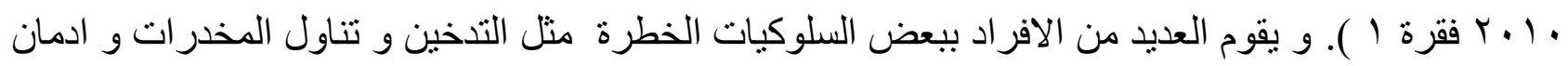

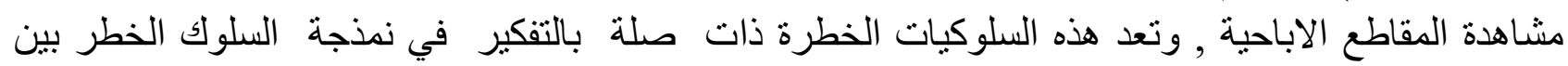

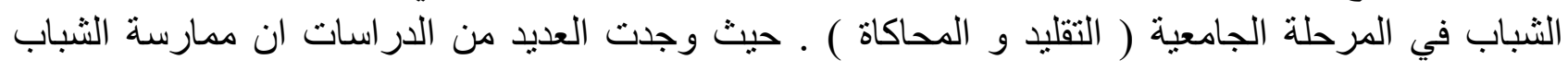
المصريين لسلوكيات الخطر هى من الاسباب الاساسية للوفاة( Refaat,A.,2004pp72-81).

و السلوك الخطر هو النشاط المعروف اجتماعيا بأنه مصدر قلق للفرد و غير مرغوب فيه اجتماعيا و مرفوض

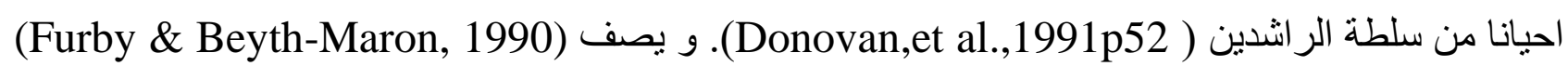

السلوك الخطر بأنه السلوك الذى ينطوي على امكانية حدوث خسارة ذاتية (Igra and Irwin ,1996 p35).

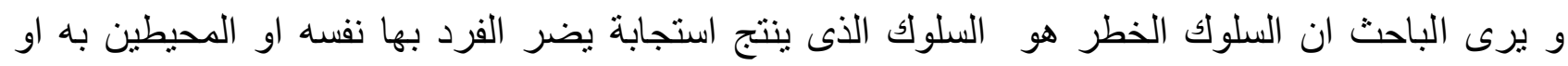

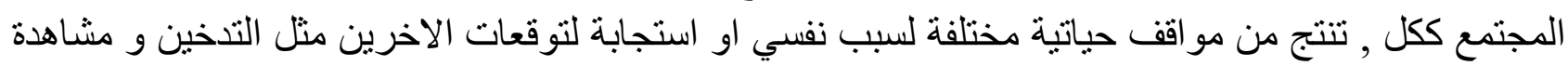

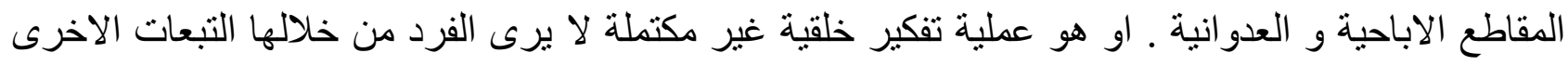

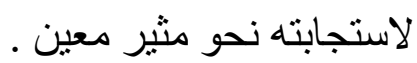

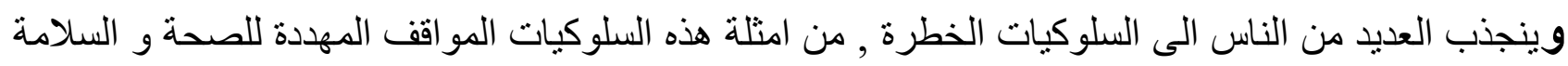

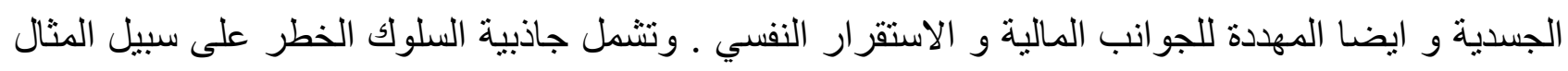

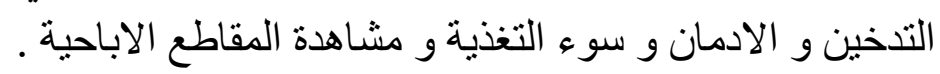

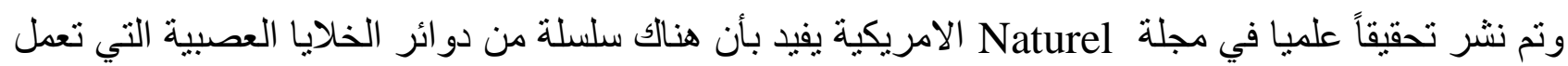

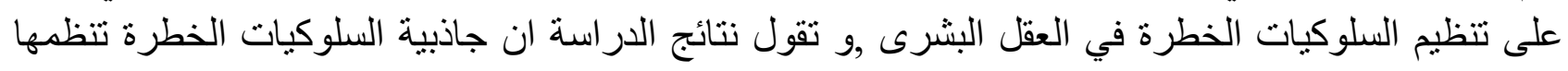

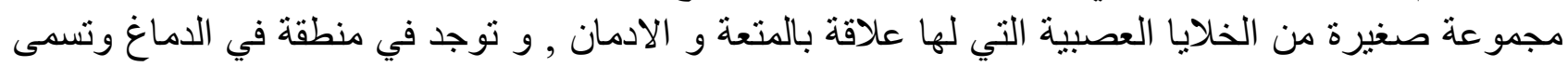

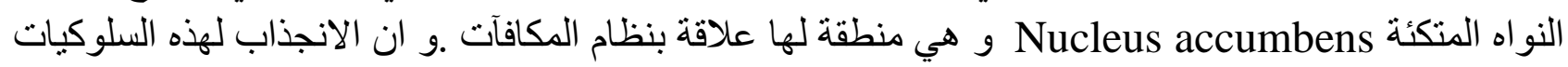


الخطرة يرتبط على نحو كبير بالسرور الذى تخلفه , حيث يزيد افراز هرمون الدوبامين Dopamine, و يعطى هذا شعورا بالسرور لبعض الافر اد (Daniel Romer et. al.2017pp19-34 ).

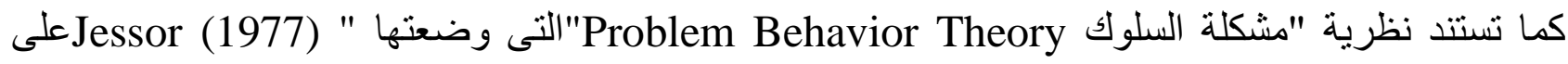

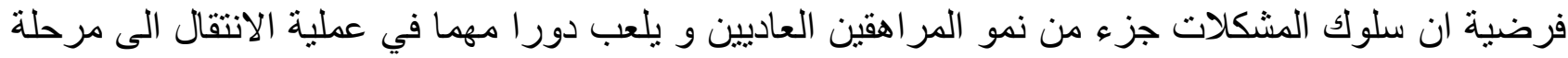

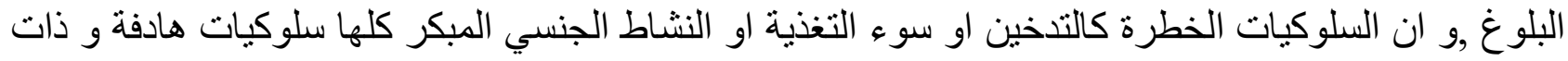

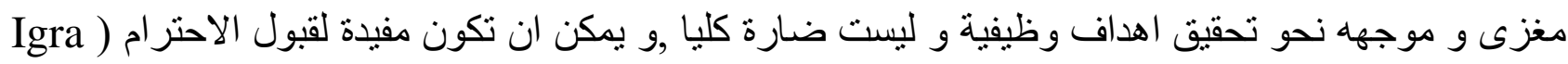
.(and Irwin ,1996 p37

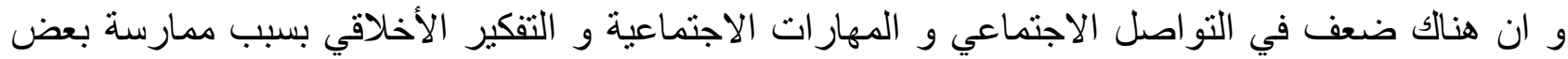

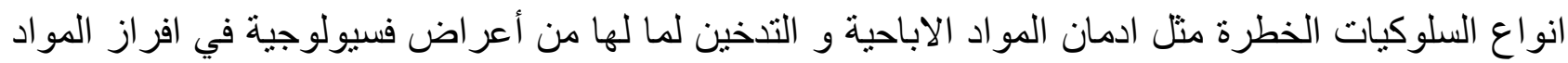

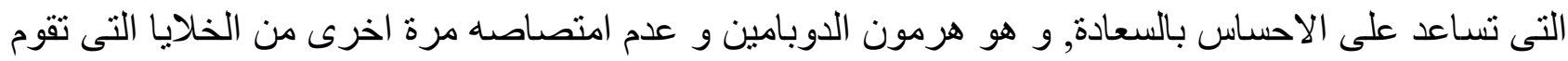

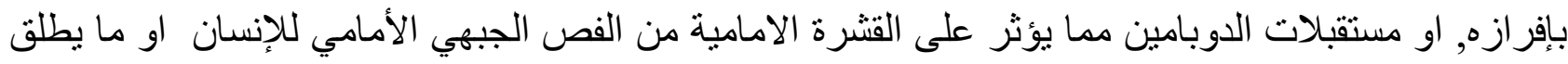

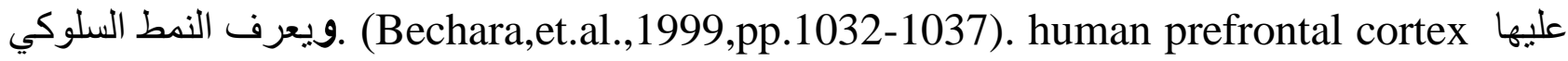
بأنه سلسلة من الافعال المنماثلة و المتشابهة المستقرة نسبياو التي يقوم بأدائها مجموعة من الافر ادواد او الجماعات

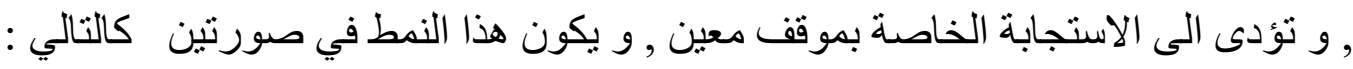

\section{1- سلوك خطر مستتر Covert Risky Behavior}

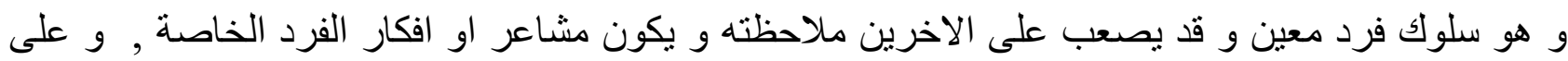

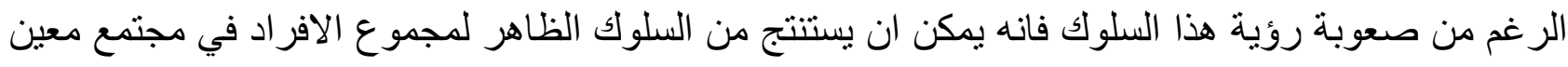
او عند قيامهم لوصف و ايضاح خبر اتهم الخاصة مثل مشاهدة المقاطع الاباحية.

\section{r Overt Risky Behavior سلوك خطر ظاهر}

و هو السلوك الفردي الذى يمكن ملاحظته و تسجيله , و يقابل السلوك الكائن الذى يستنتج من المشاعر و و الأفكار

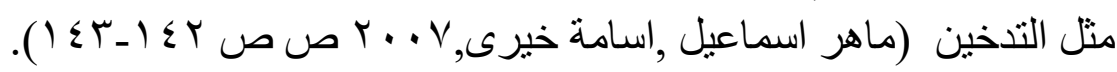

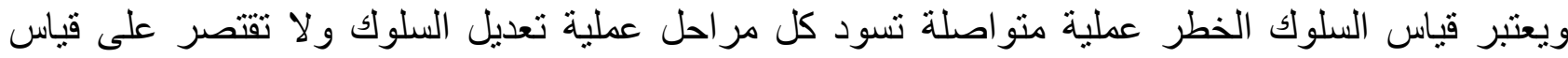

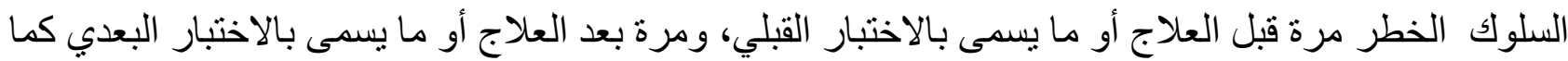

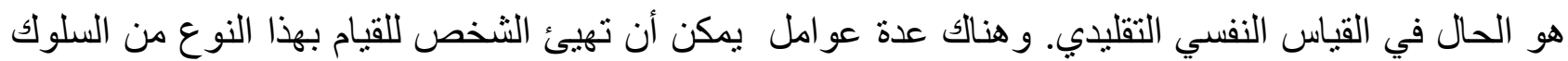

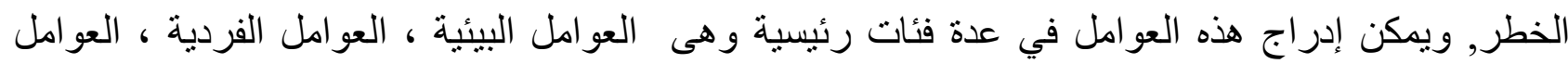

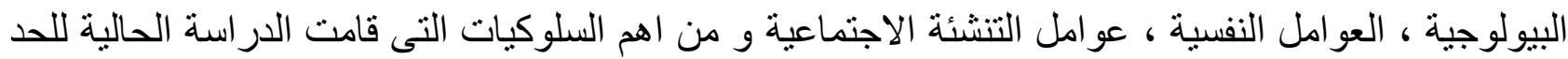

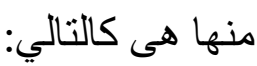

\section{اولا : التدخين كسلوك خطر :}

التنخين Smoking هو عملية ينم فيها حرق مادة التبغ او الاخان كما يطلق عليها, ومن ثم يتم تذوق الدخان

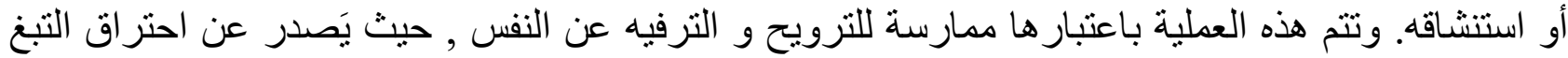

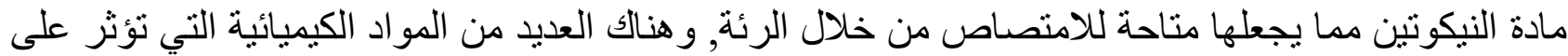

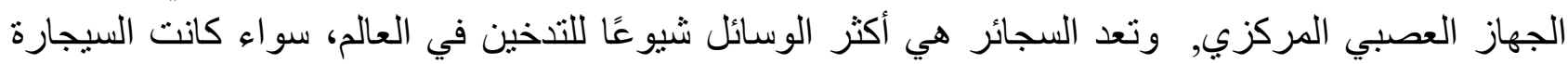




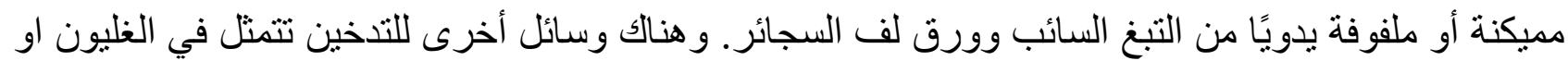

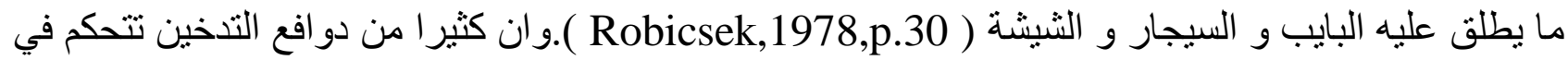

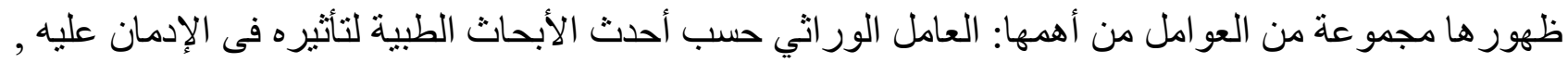

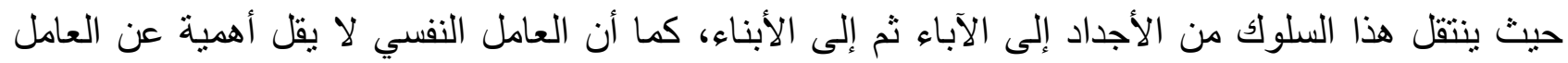

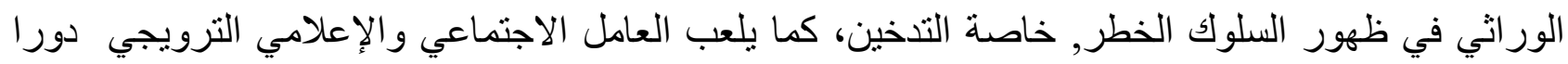

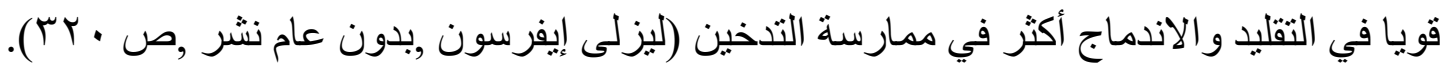

\section{ثانيا : ادمان الصور و المقاطع المثيرة جنسيا كسلوك خطر .}

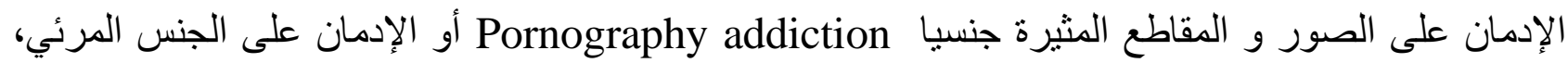

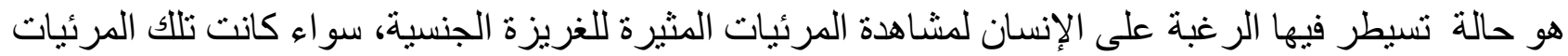

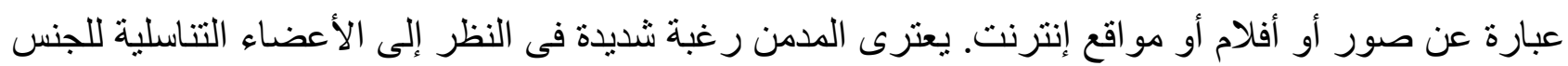

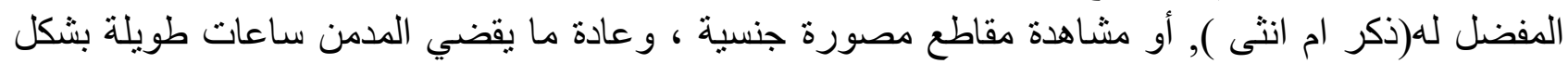

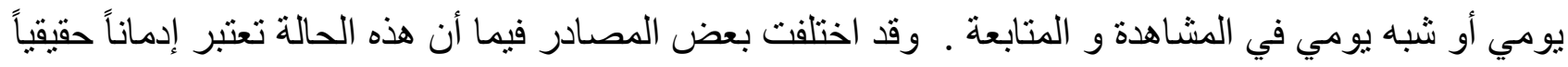

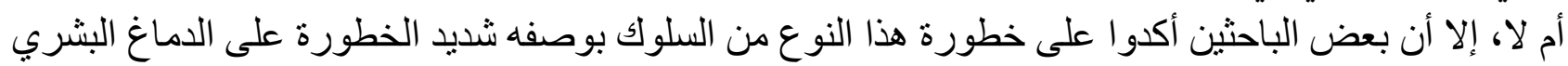

.(Smitha Bhandari,2019,para.1)

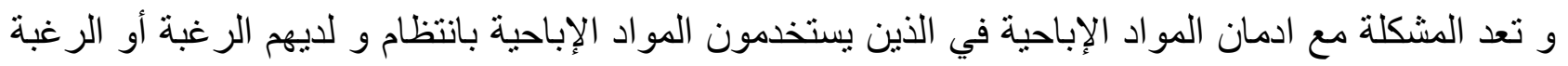

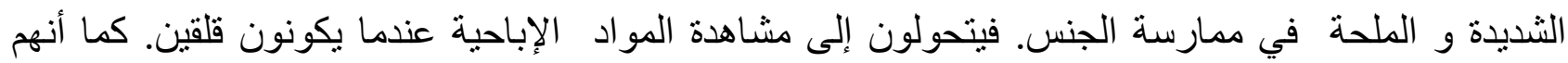
يميلون إلى النضال في العمل و المنزل.(Smitha Bhandari,2019,para.2).

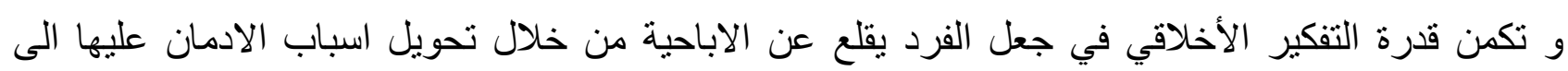

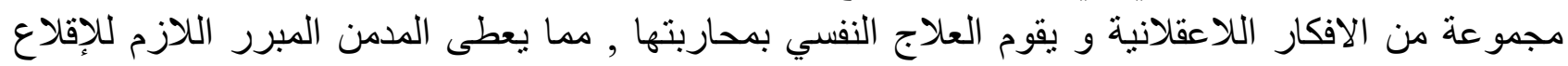
عنها.

ثالثا : العدوانية كسلوك خطر :

عرف (Kuffman,1985,pp.806) السلوك العدواني بأنه " سلوك يقصد به الاساءة و الاذى للأشخاص

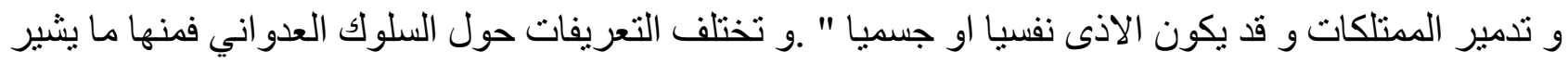

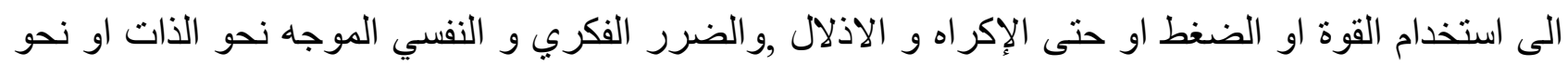

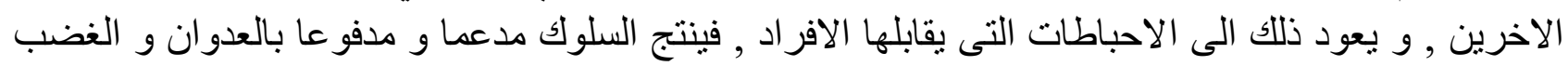
و الكر اهية .

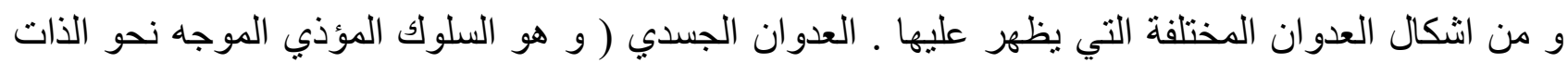

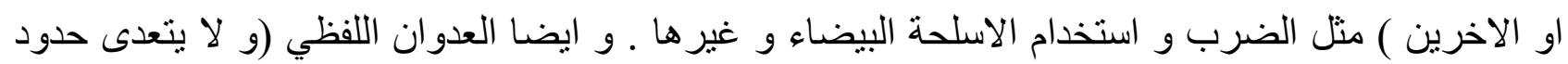

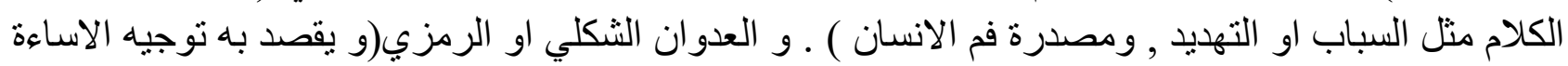

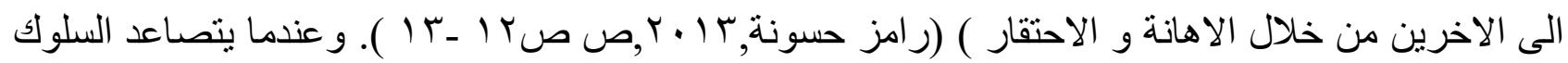

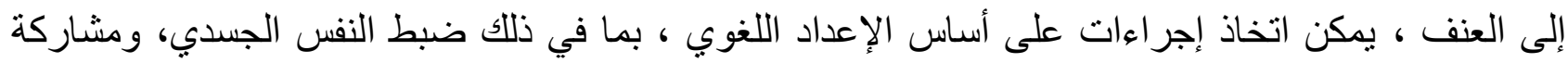
الثرطة (Murphy,Amy\&Brunet,Brain., 2008,pp.66-70). 
اولا: بعض الدراسات السابقة التي تناولت مفهوم التفكير الأخلاقي و علاقته ببعض المتنغيرات الاخرى,

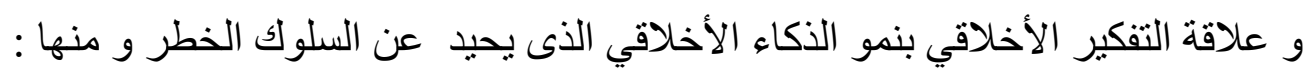

دراسة Matarazzo, Olimpia and Abbamonte, Lucia and Nigro, Giovanna (ل⿳⺈⿴囗十

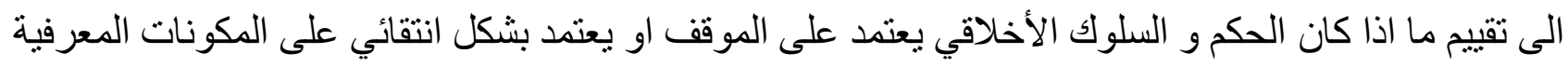

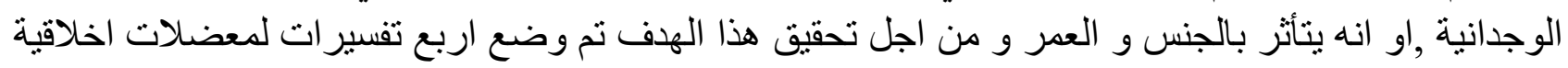

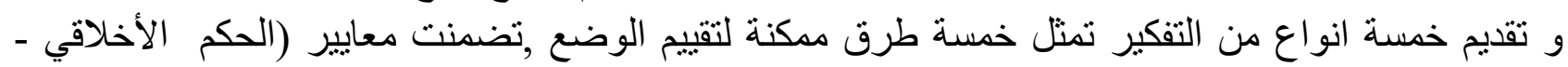
الانانية ـ الايثار - الاحساس بالعدالة ـ الصر اعن بين الانانية و المسائل الاخلاقية ).

و قد اجرت ميسون محمد (9 . . ب) در اسة هدفت الى الكثف عن مستوى التفكير الأخلاقي و مستوى المسئولية

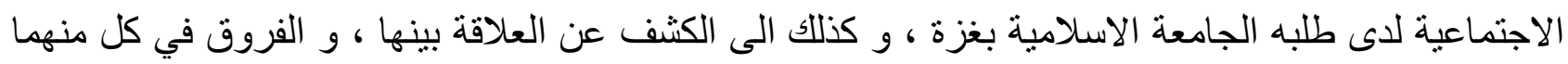

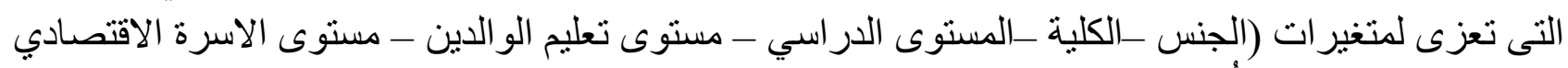

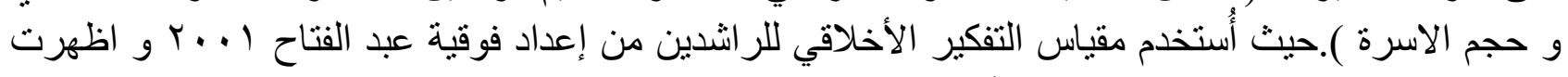

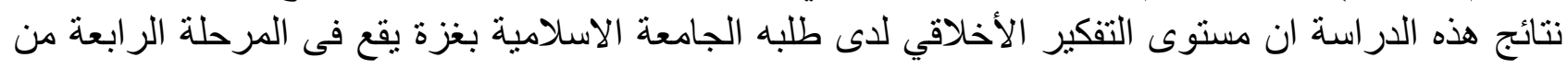

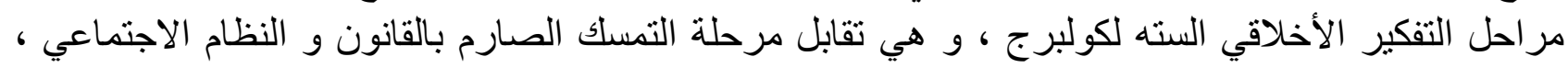

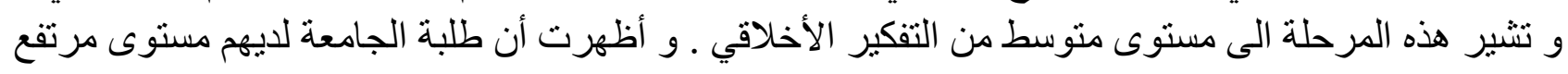

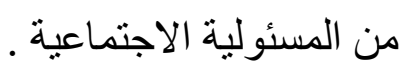

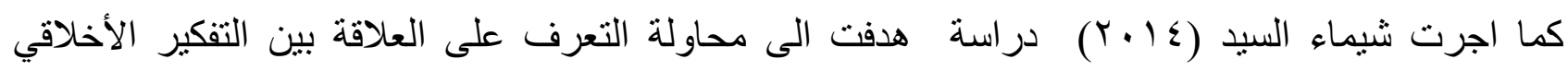

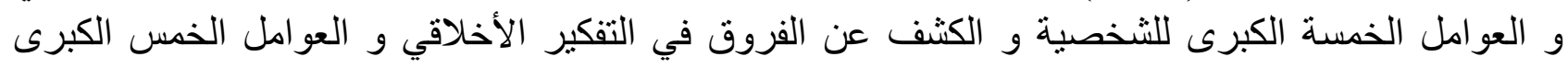

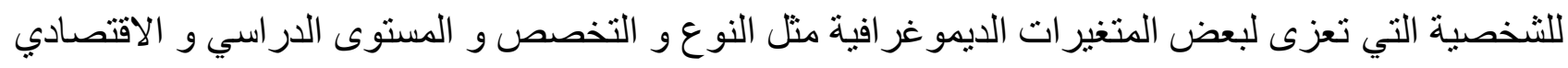

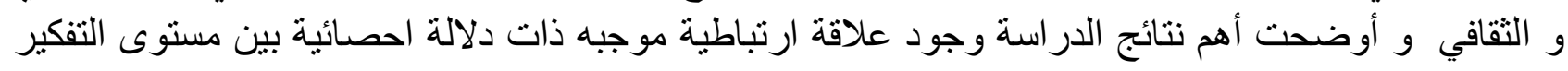

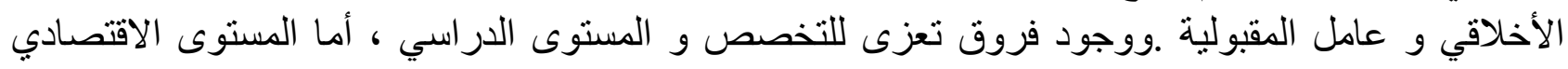

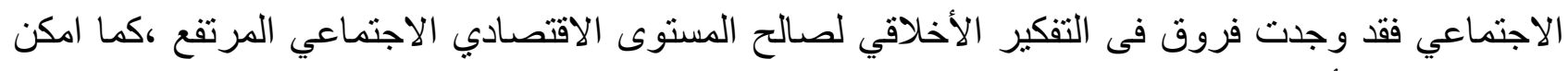

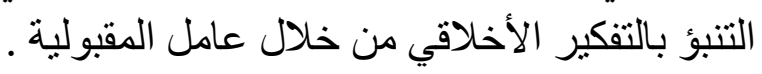

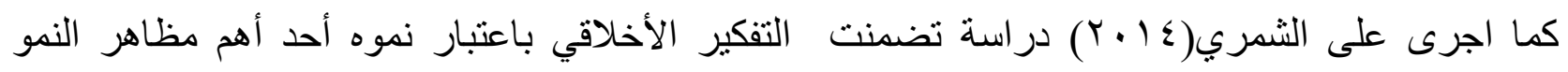

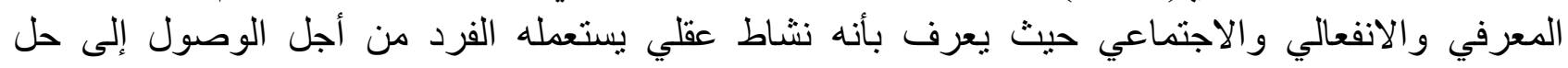

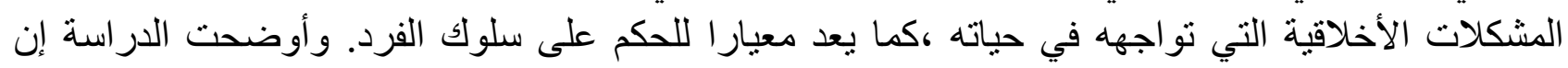

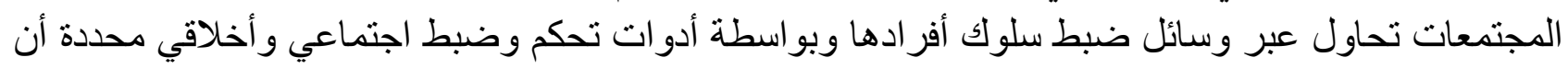

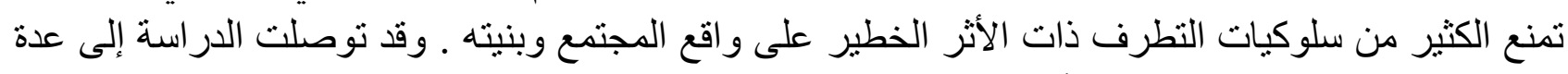

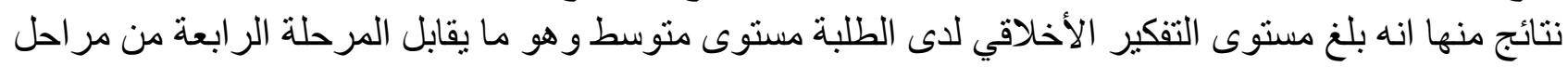

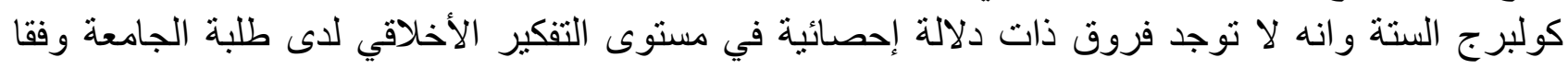
لكتغير النوع مع وجود هذه الفروق من حيث التخصص. 


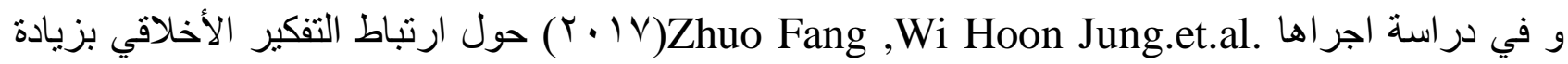

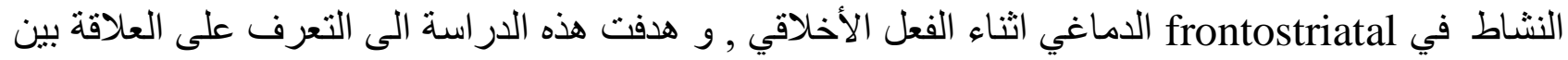

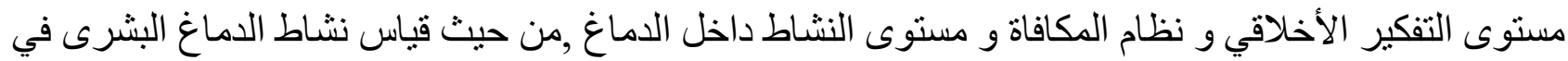

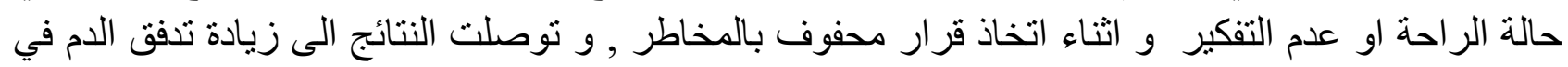

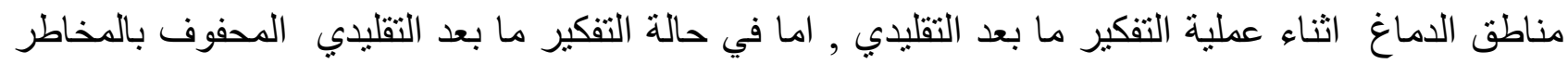

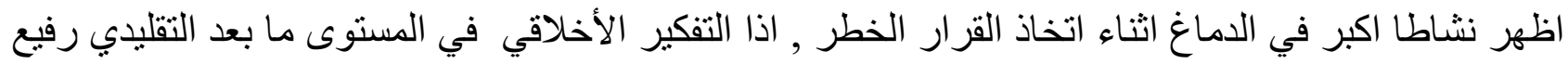

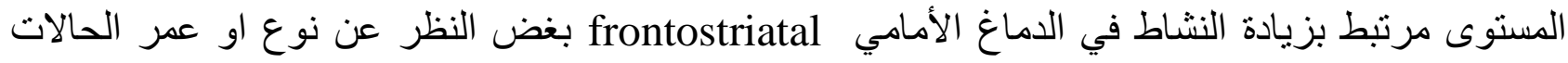

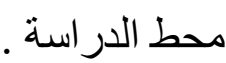

ثانيا :دراسات سابقة تناولت مفهوم السلوك الخطر و علاقته ببعض المتغيرات الاخرى و هى كالتالي : ففي دراسة لـ Thessandro

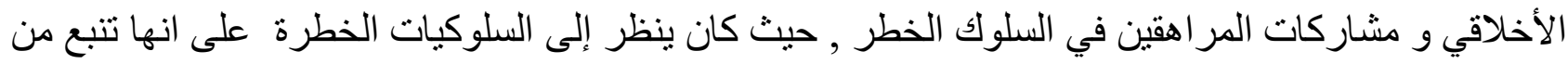

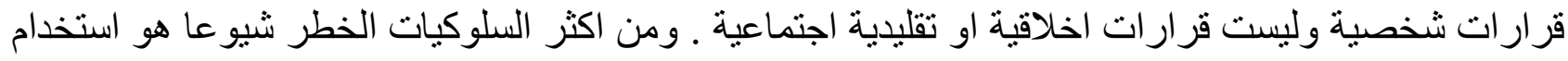

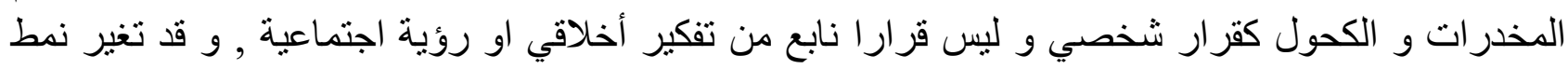

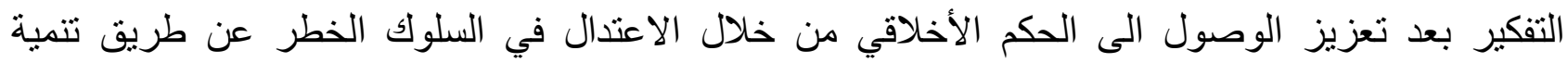

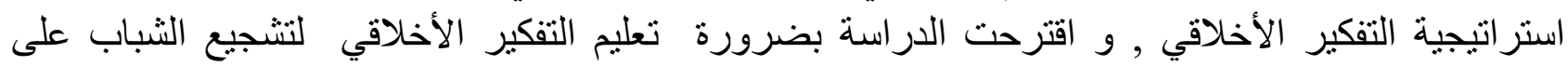

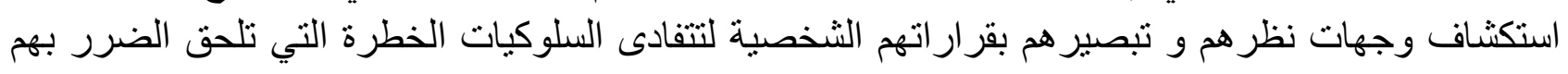
و بمجتمعهم .

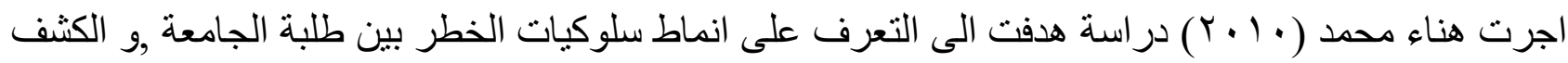

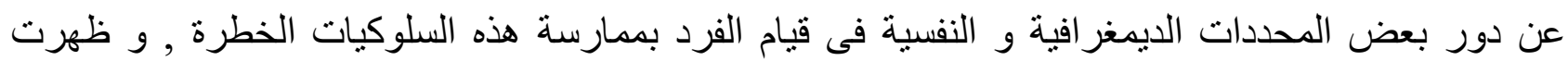

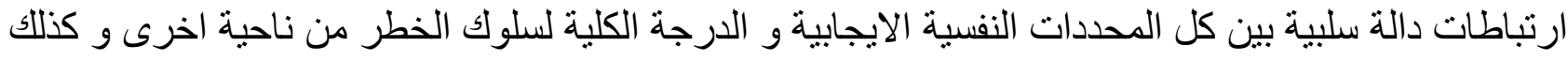

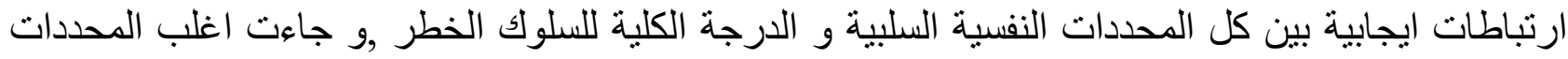

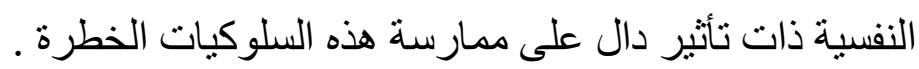

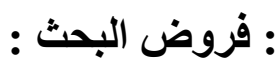

و يمكن الاستفادة من الدر اسات السابقة فى وضع فروض الدر اسة الحالية و مناقشتها مع نتائج الدر اسة كالتالي : نتائج الاراسة و تفسير ها :

الفرض الاول: لا توجد فروق ذات دلاله احصائية بين متوسطات درجات أفر اد المجموعة التجرييية و بين

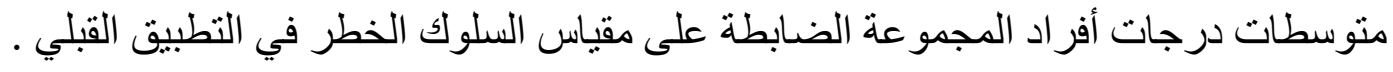
و لاختبار الفرض الاول , تم حساب دلالة الفروق بين منوسطات درجات افراد المجموعة التجرييية و الضابطة

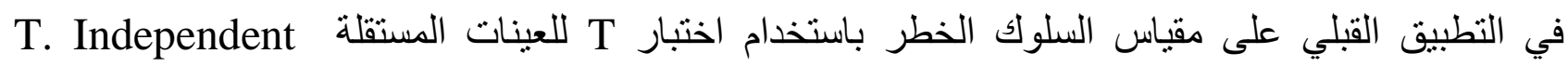

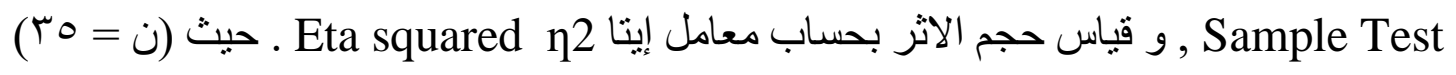




\begin{tabular}{|c|c|c|c|c|c|c|c|c|c|}
\hline الدلالة & $\begin{array}{c}\text { Effect } \\
\text { size }\end{array}$ & $\eta^{2}$ & $\begin{array}{l}\text { Sig.(2tail } \\
\text { ed) }\end{array}$ & $\mathbf{T}$ & $\begin{array}{l}\text { Std.Devia } \\
\text { tion }\end{array}$ & Mean & \multicolumn{2}{|c|}{ المجموع } & الابعاد \\
\hline \multirow{2}{*}{ ليست } & \multirow{2}{*}{ small } & \multirow{2}{*}{0.01} & \multirow{2}{*}{0.265} & \multirow{2}{*}{1.123} & 10.459 & 147.71 & تجريبي & \multirow{2}{*}{ قبلي } & \multirow{2}{*}{ الكلية } \\
\hline & & & & & 10.190 & 150.49 & ضابطة & & \\
\hline
\end{tabular}

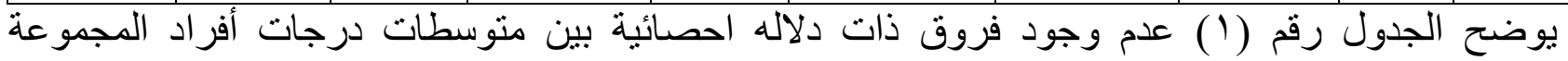

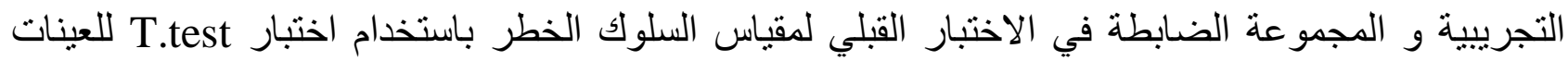

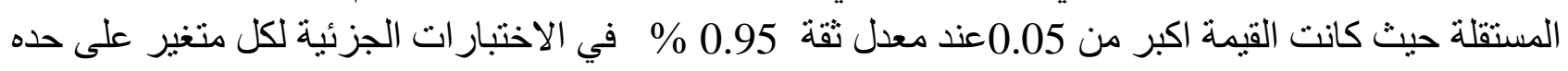

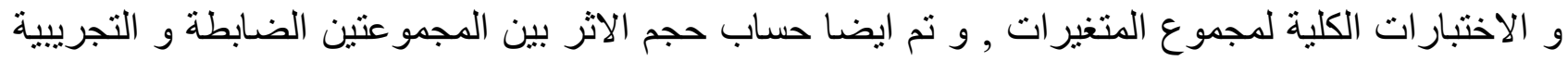

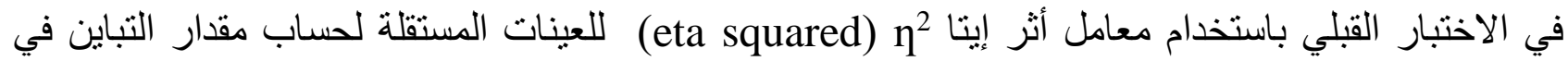

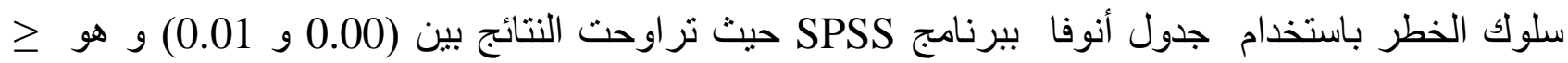

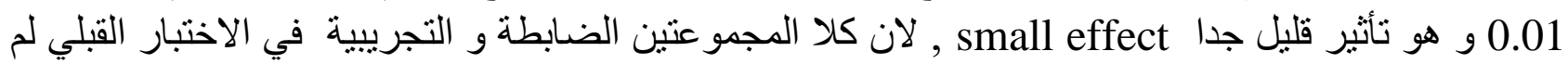

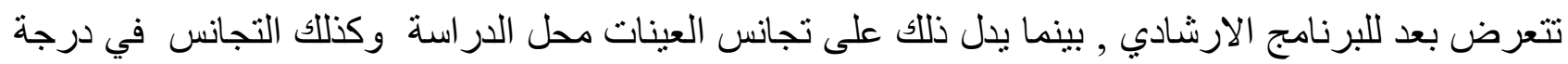

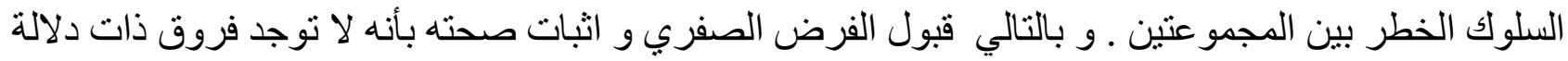

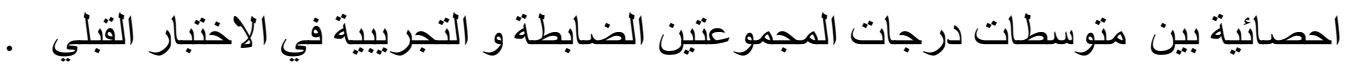

الفرض الثاني : توجد فروق ذات دلالة احصائية بين متوسطات درجات أفراد المجمو عة التجريبية على مقياس

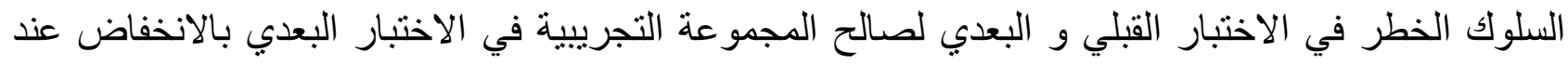

$$
\text { مستوى دلالة ج } 0.05 .
$$

و لاختبار الفرض الثاني , تم حساب دلالة الفروق بين منوسطات درجات افر اد المجمو عة التجريبية في التطبيق

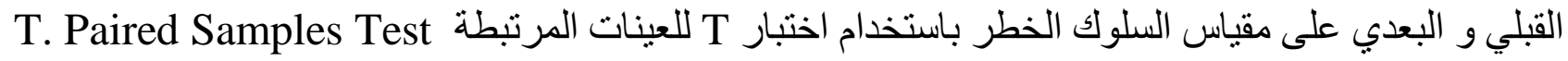

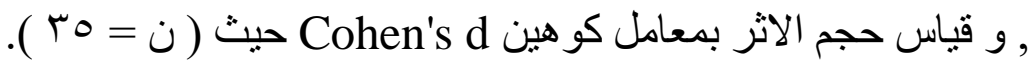

\begin{tabular}{|c|c|c|c|c|c|c|c|c|c|}
\hline الدلالة & $\begin{array}{c}\text { Effect } \\
\text { size }\end{array}$ & d. & $\begin{array}{l}\text { Sig. }(2 t \\
\text { ailed) }\end{array}$ & $\mathbf{T}$ & $\begin{array}{c}\text { Std.Devi } \\
\text { ation }\end{array}$ & Mean & \multicolumn{2}{|c|}{ المجموع } & الابعاد \\
\hline \multirow{2}{*}{ داله } & \multirow{2}{*}{ medium } & \multirow{2}{*}{0.35} & \multirow{2}{*}{0.00} & \multirow{2}{*}{12.574} & 8.511 & 161.91 & قبلي & \multirow{2}{*}{ تجرييية } & الدرجة \\
\hline & & & & & 9.246 & 148.43 & بعدي & & (آكليها \\
\hline
\end{tabular}

يشير الجدول رقم (r) الى وجود فروق ذات دلالة احصائية بين متوسطات درجات افر اد المجموعة التجريبية

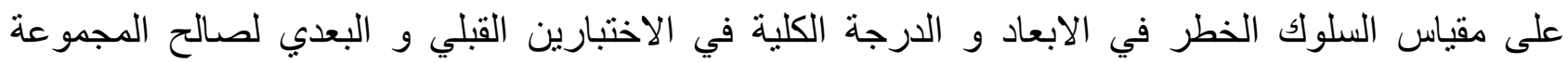
التجريبية بانخفاض السلوك الخطر عند مستوى دلالة ج 0.05 ـ باستخدام اختبار T للعينات المرتبطة.

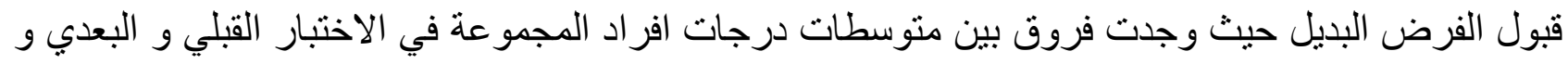

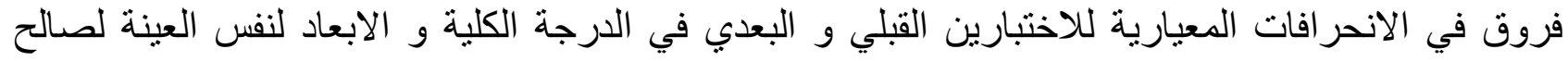

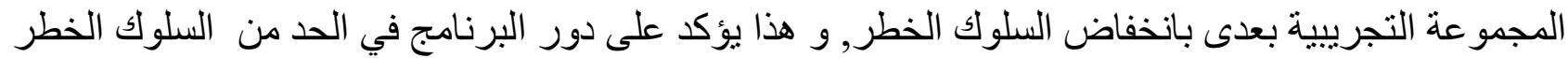

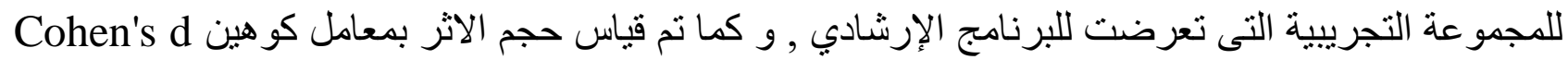


حيث كانت قيمة (d) تثير الى وجود اثر متوسط medium ويثير ذللك طبقا لمعامل كو هين الى وجود أثر كبير

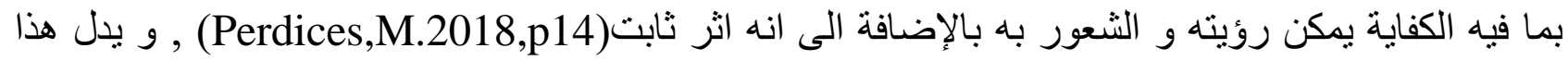

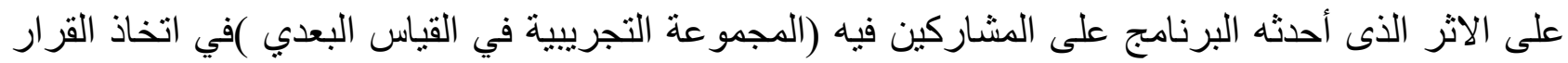

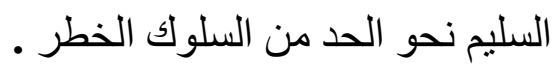

الفرض الثالث: لا توجد فروق ذات دلالة احصائية بين منوسطات درجات أفراد المجموعة الضابطة في

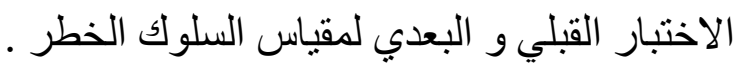

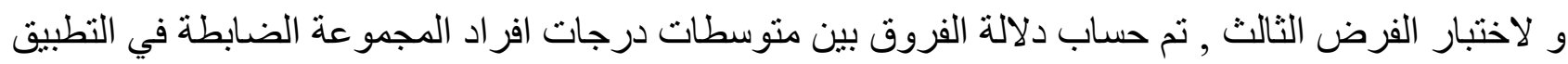
القبلي و البعدي على مقياس السلوك الخطر باستخدام اختبار T للعينات المرتبطة و قياس حجم الاثر بمعامل

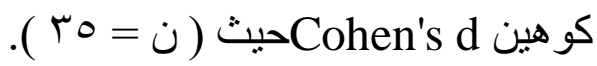

\begin{tabular}{|c|c|c|c|c|c|c|c|c|c|}
\hline الدلالة & $\begin{array}{c}\text { Effect } \\
\text { size }\end{array}$ & d. & $\begin{array}{l}\text { Sig.(2ta } \\
\text { iled) }\end{array}$ & $\mathbf{T}$ & $\begin{array}{l}\text { Std.Deviat } \\
\text { ion }\end{array}$ & Mean & \multicolumn{2}{|c|}{ المجموع } & الابعاد \\
\hline \multirow[t]{2}{*}{ ليست دالة } & \multirow[t]{2}{*}{ small } & \multirow[t]{2}{*}{0.00} & \multirow{2}{*}{0.160} & \multirow{2}{*}{1.435} & 8.581 & 161.31 & قبلي & \multirow[t]{2}{*}{ ضابطة } & الدرجة \\
\hline & & & & & 8.633 & 161.14 & بعدي & & أكليه \\
\hline
\end{tabular}

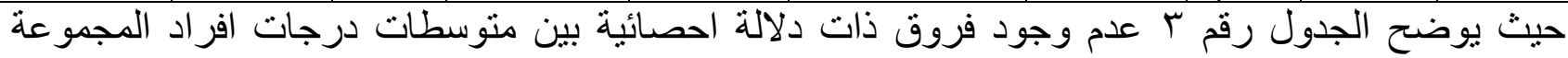

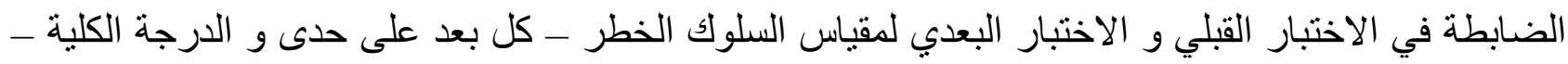

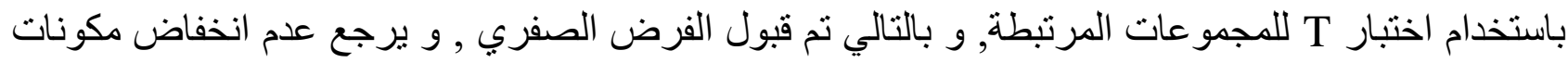

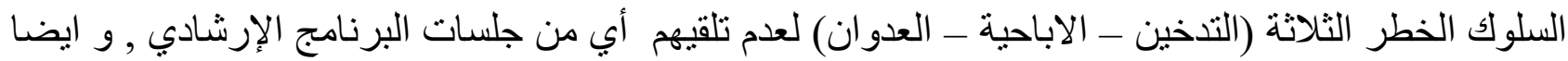

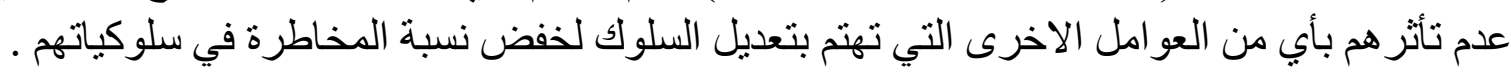

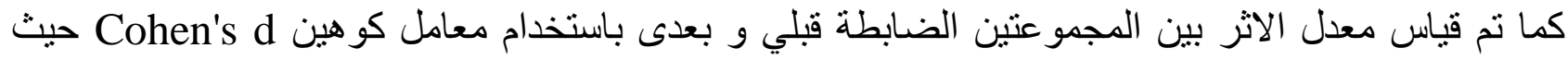

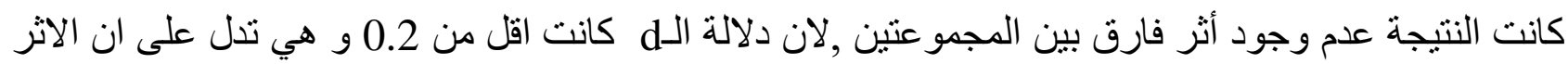
small

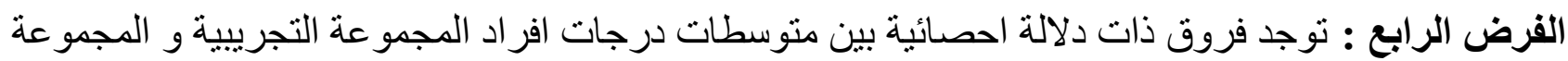

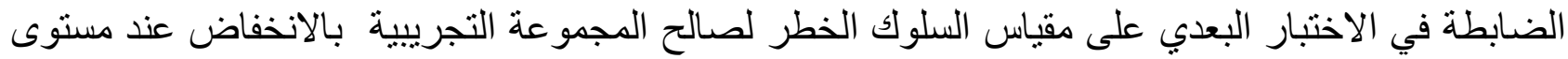

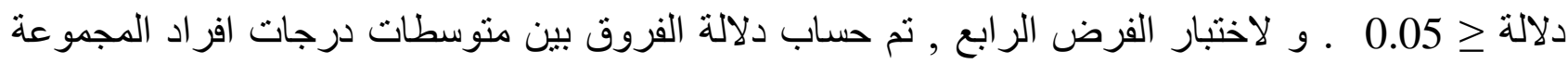

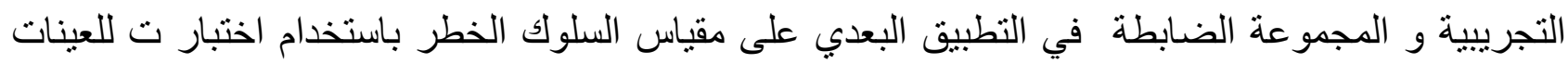

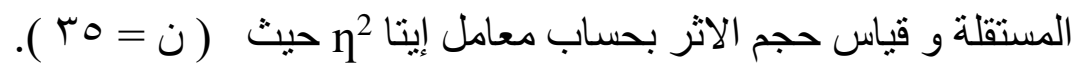

\begin{tabular}{|c|c|c|c|c|c|c|c|c|c|}
\hline الدلالة & $\begin{array}{c}\text { Effect } \\
\text { size }\end{array}$ & $\eta^{2}$ & $\begin{array}{l}\text { Sig.(2ta } \\
\text { iled) }\end{array}$ & $\mathbf{T}$ & $\begin{array}{c}\text { Std.Devia } \\
\text { tion }\end{array}$ & Mean & \multicolumn{2}{|c|}{ المجموع } & الابعاد \\
\hline \multirow[t]{2}{*}{ داله } & \multirow[t]{2}{*}{ large } & \multirow[t]{2}{*}{0.24} & \multirow[t]{2}{*}{0.000} & \multirow[t]{2}{*}{4.728} & $\begin{array}{l}6.919 \\
02446\end{array}$ & $\begin{array}{l}157.66 \\
148.43\end{array}$ & ضابطة & \multirow[t]{2}{*}{ بعدى } & الالارجة \\
\hline & & & & & 9.246 & 148.43 & نجريبيا & & \\
\hline
\end{tabular}

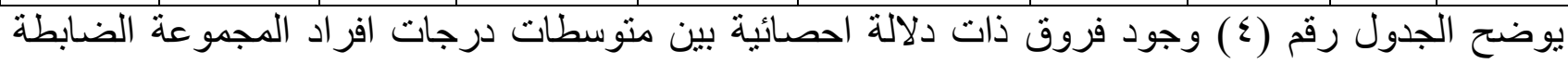

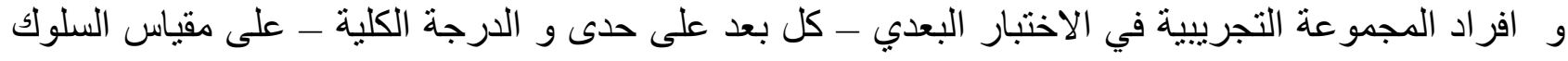


الخطر بالانخفاض لصالح المجموعة التجريبية في الاختبار البعدي و بالتالي قبول الفرض البديل ,حيث

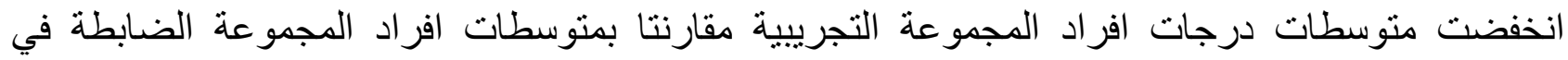

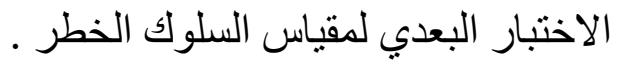

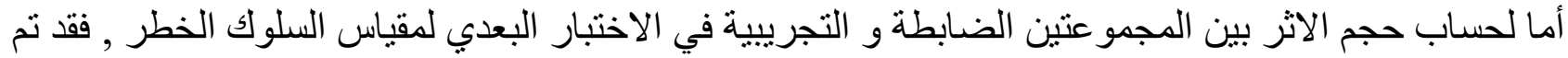

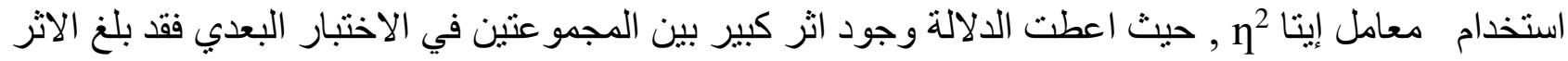

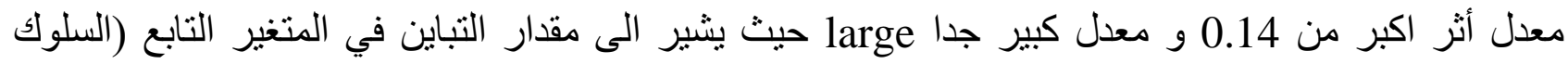
الخطر ) بالانخفاض لصالح المجموعة التجريبية في الاختبار البعدي.

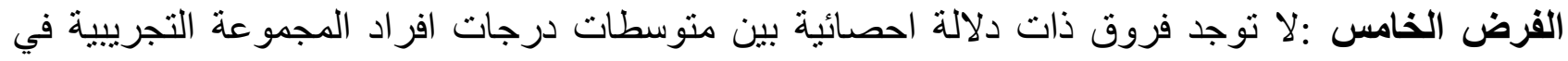

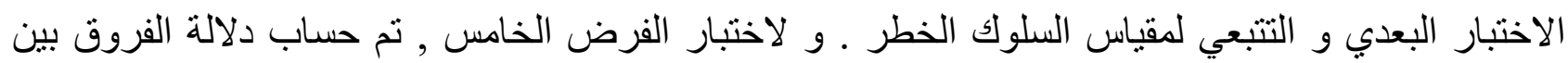

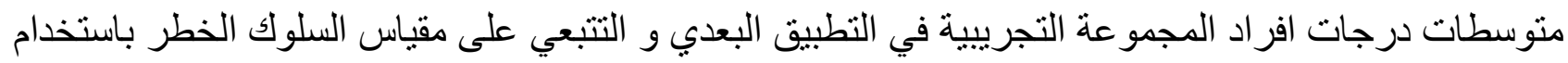

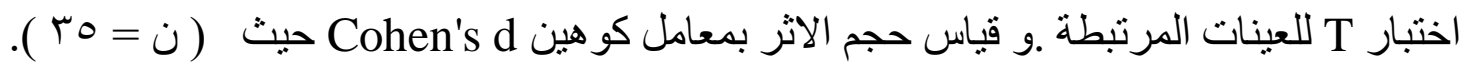

\begin{tabular}{|c|c|c|c|c|c|c|c|c|c|}
\hline الدلالة & $\begin{array}{c}\text { Effect } \\
\text { size }\end{array}$ & d. & $\begin{array}{l}\text { Sig. }(2 t \\
\text { ailed })\end{array}$ & $\mathbf{T}$ & $\begin{array}{c}\text { Std.Devia } \\
\text { tion }\end{array}$ & Mean & \multicolumn{2}{|c|}{ المجموع } & الابعاد \\
\hline \multirow[t]{2}{*}{ دالة } & \multirow[t]{2}{*}{ small } & \multirow[t]{2}{*}{0.08} & \multirow[t]{2}{*}{0.005} & \multirow[t]{2}{*}{3.004} & 9.246 & 148.43 & بعدي & \multirow[t]{2}{*}{ تجريبية } & الارجة \\
\hline & & & & & 8.985 & 149.57 & تتبعي & & \\
\hline
\end{tabular}

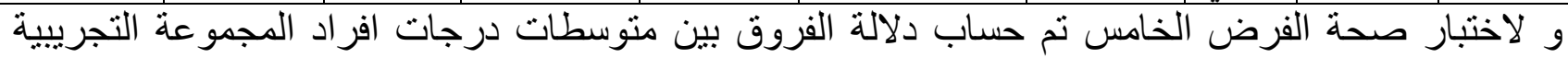

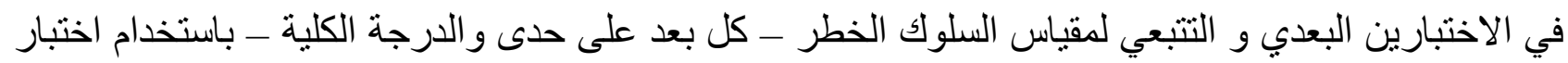

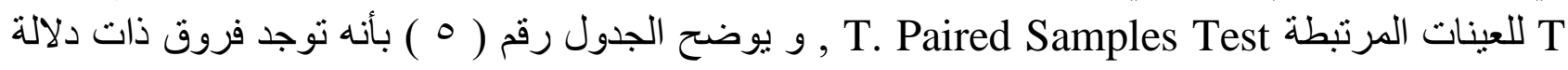

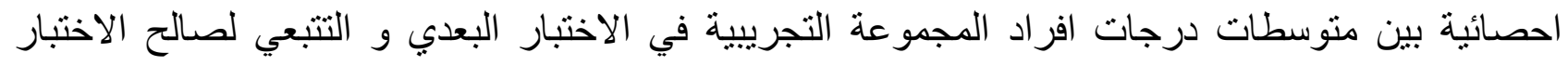

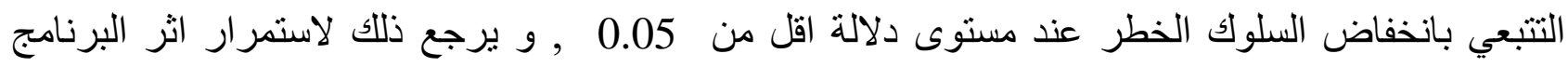

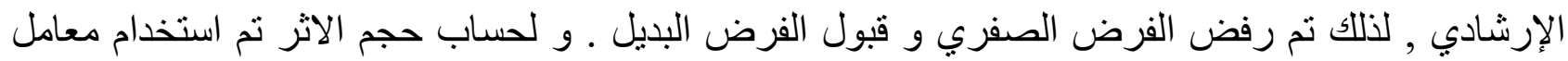

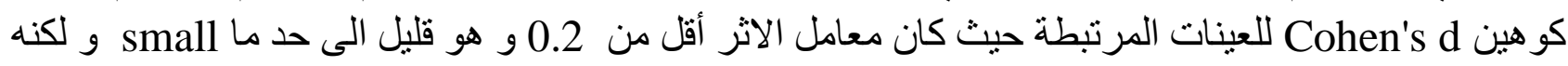

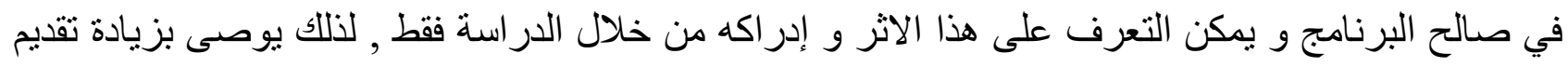

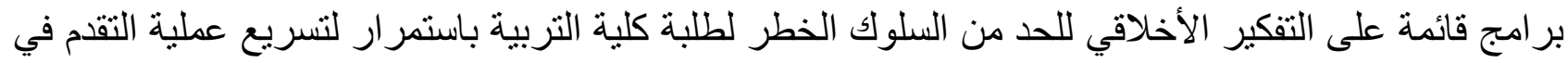

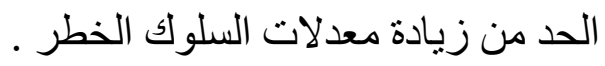
ثانيا : تعليق عام على نتائج الدراسة :

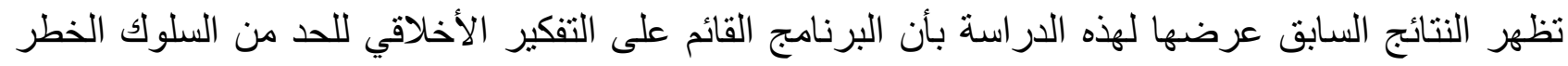

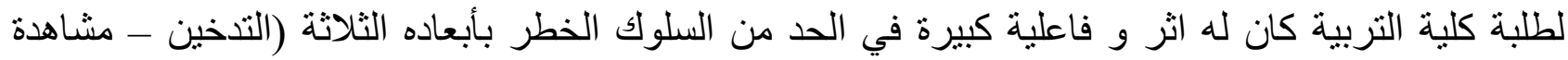

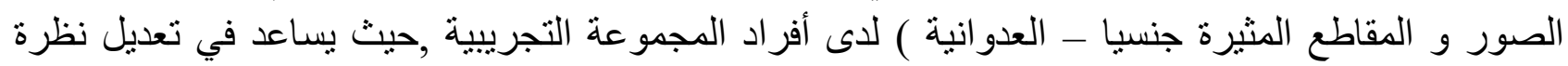

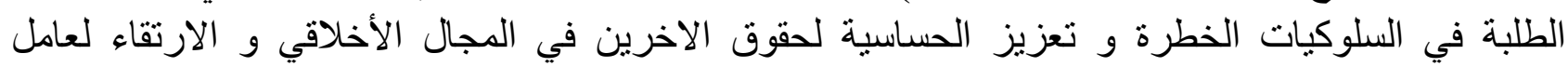

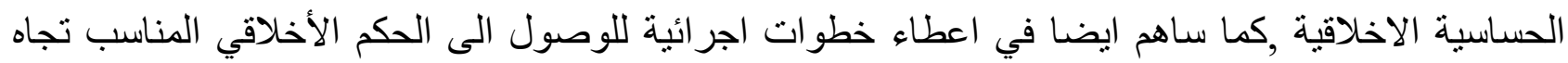

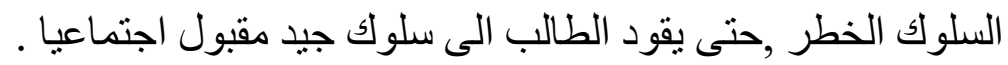




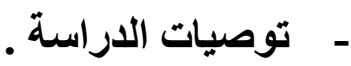

يمكن استخلاص مجمو عة من التوصيات المنبثقة من نتائج الدراسة الحالية و هى كالتالى : ا ـ الاستفادة من برنامج الدراسة الراهنة في الحد من السلوكيات الخطرة اعتمادا على استر اتيجية التفكير

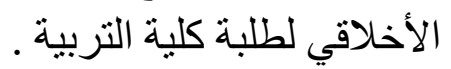

$$
\text { r- اعتماد مقياس السلوك الخطر بأبعاده الثناثة (التدخين - الإباحية - العدو انية ). }
$$

r- زيادة التوعية بأنواع السلوك الخطر المختلفة التي يمارسها الطلبة داخل حرم كلية التربية .

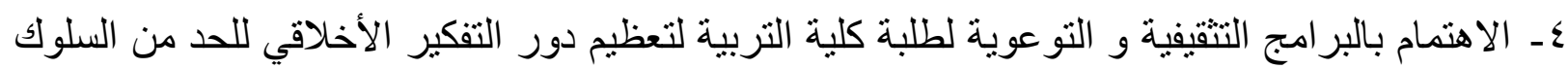

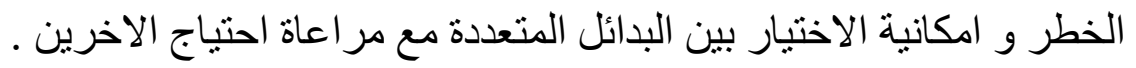

هـ اعتماد استراتيجية التفكير الأخلاقي كأداة يمكنها التوغل داخل البنية المعرفية للطالب لتعديل السلوك

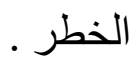
ا- اعتماد مقرر در اسي جديد لطلبة الكلية يحتوى على استراتيجية للتفكير الأخلافي و أثرها في الحد من

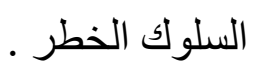

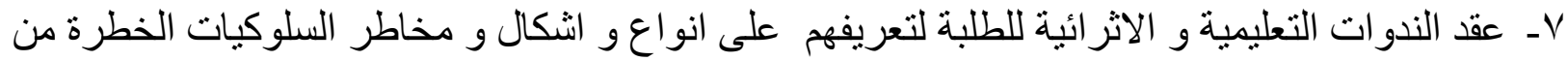

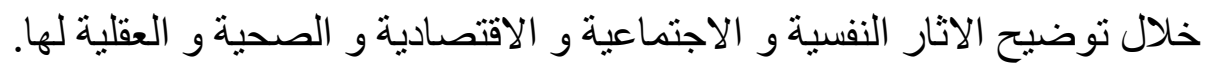

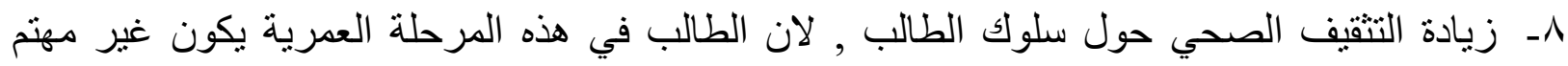

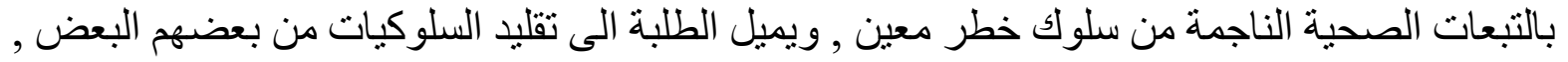

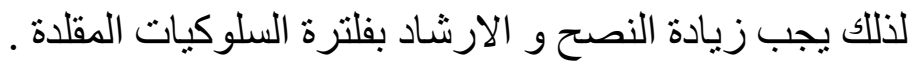

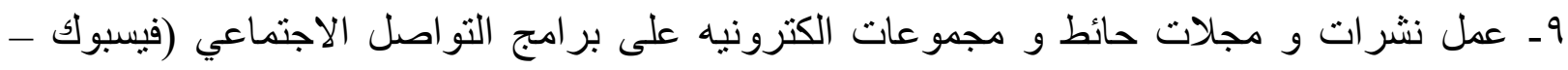

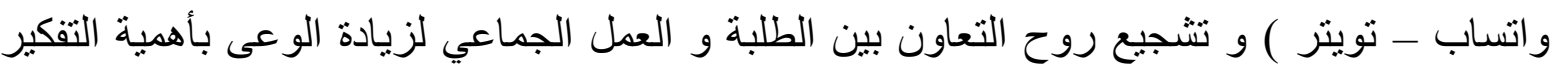

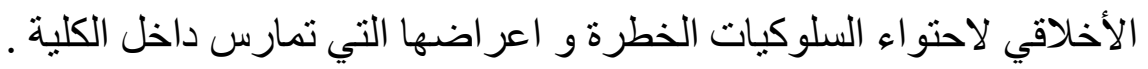

رابعا :البحوث و الدراسات المقترحة :

1 ـ فاعلية برنامج قائم على التفكير الأخلافي للحد من السلوك المضاد للمجتمع . r ـ فاعلية برنامج قائم على التفكير الأخلافي للحد من سلوك ايذاء الذات. rـ فاعلية برنامج إرشادي لرفع مستوى التفكير الأخلاقي لخفض السلوك الخطر للى طلبة الجامعة. عـ فاعلية برنامج قائم على التفكير الأخلاقي لتنمية الرقابة الذاتية . 


\section{المراجع}

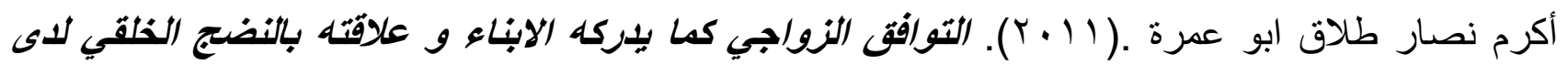

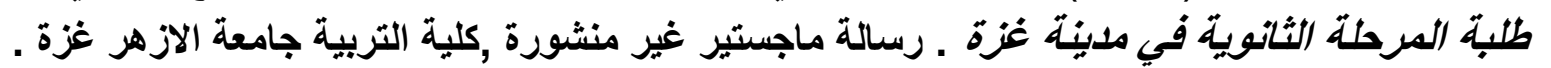

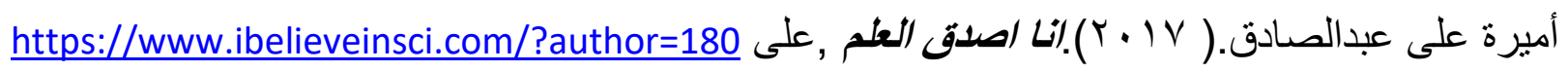

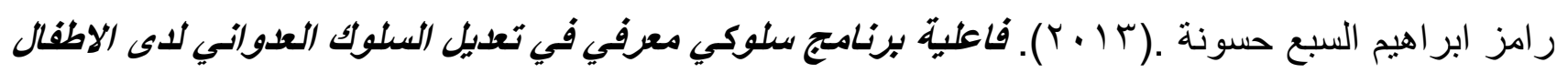

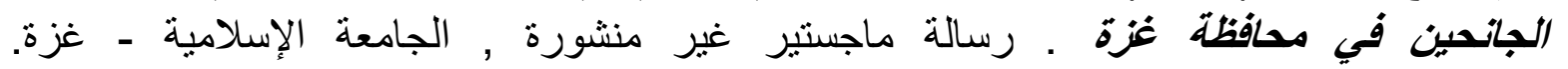

\section{http://hdl.handle.net/20.500.12358/19213}

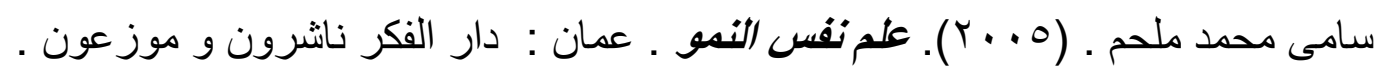

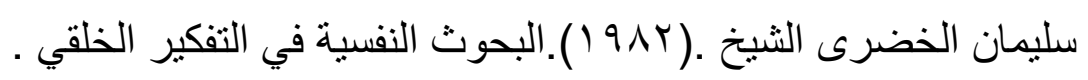

سيد احمد عثمان (997 (19). التحليل الأخلاقي للمسئولية الاجتماعية . القاهرة :مكتبة الانجلو المصرية. عادل عبد الله محمد (T 1 •r).اسس البحث العلمي في ضوء التعديلات الواردة في APA5.الرياض :دار

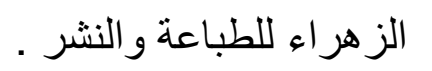

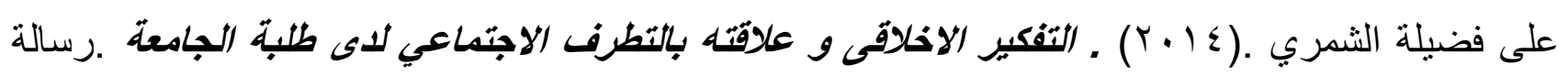

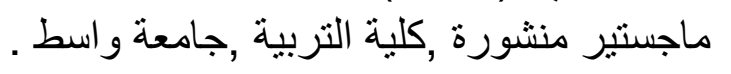

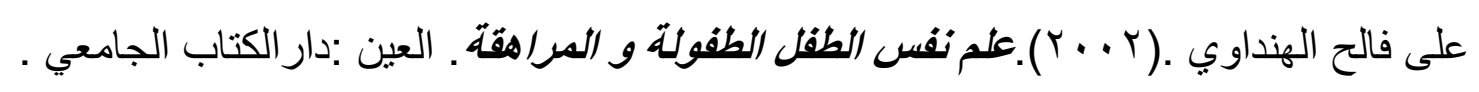
عزة حسين ذكى.(919 ( ) ). برنامج إرشادي لمو/جهة مشكلة العدوانية لدى المراهقين - رسالة دكتور اه غير

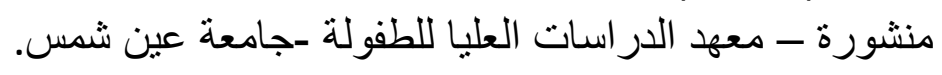

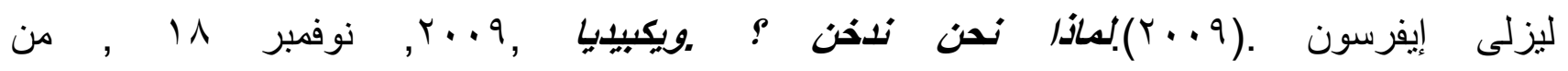
https://ar.wikipedia.org/wiki/\%D8\%AA\%D8\%AF\%D8\%AE\%D9\%8A\%D9\%86

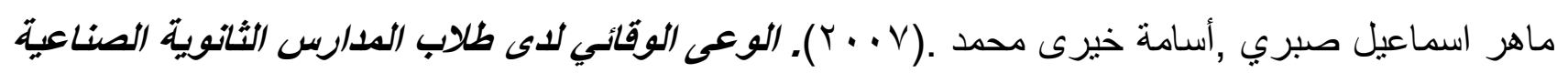

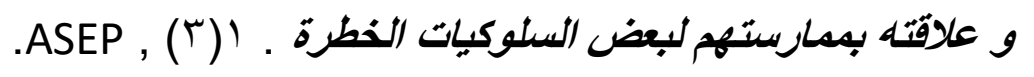

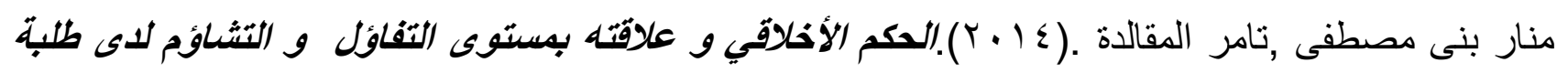

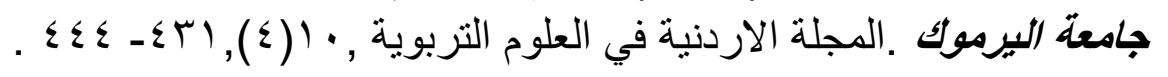

محمد السيد عبد الرحمن (991 ().مقياس التوجه نحو المساعدة ودراسات فى الصحة النفسية مهارات

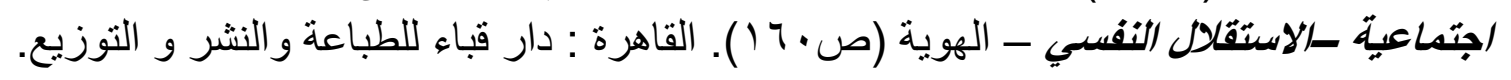

منى محمد على جاد (ع . . ب).التربية البيئية فى الطفولة المبكرة و تصنيفاتها (ط ). القاهرة :دار المسيرة

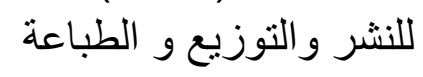




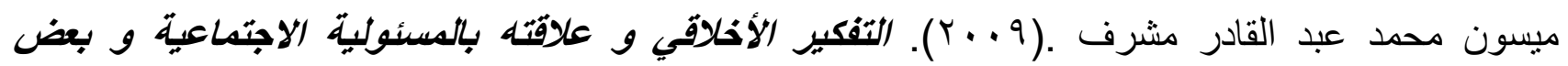

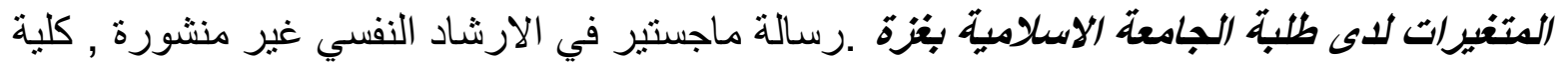

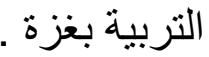

نبيه إبر اهيم اسماعيل (ب9 (199).اصلائة الشخصية- ضرورتها - مفهومها - قياسها .شبين الكوم: مطابع الولاء

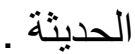

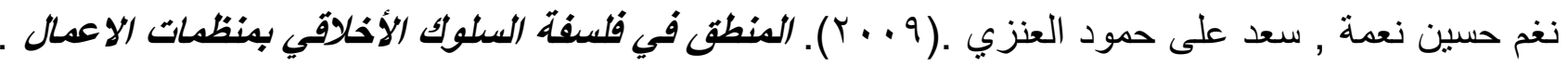

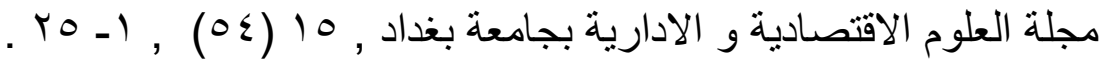

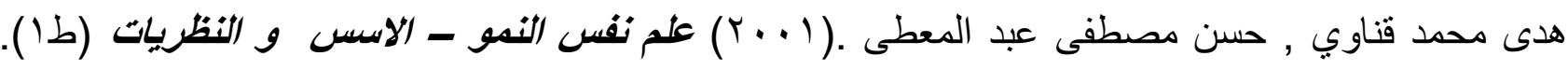
القاهرة : دار قباء للطباعة و النشر . لمبعل

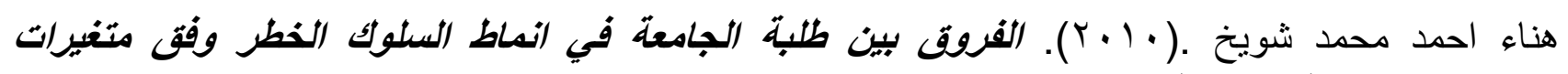

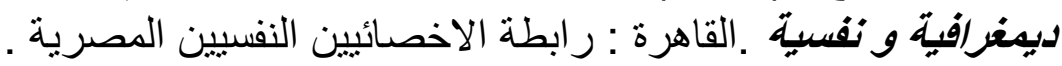

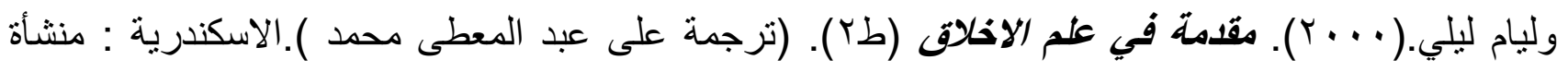

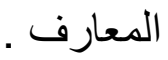

Bhandari,S.(2019 ,19 March ).Pornography Addiction . web. ,MD. Medical reference.

BORBA, M. D. C., \& SKOVSMOSE, O. (2001). A ideologia da certeza em educação matemática. SKOVSMOSE, O. Educação matemática crítica: a questão da democracia, 2, 127-148.

Campbell, W. C., Cavico, F. J., Pellet, P. F., \& Mujtaba, B. G. (2010). Applying Moral Development Literature And Ethical Theories To The Administration Of Taxes In Kosovo. International Business \& Economics Research Journal (IBER), 9(7).

Donovan, J. E., Jessor, R., \& Costa, F. M. (1991). Adolescent health behavior and conventionality-unconventionality: An extension of problem-behavior therapy. Health Psychology, 10(1), 52.

Elliott, S. J., Wainwright, L. A., McDaniel, T. K., Jarvis, K. G., Deng, Y., Lai, L. C., ... \& Kaper, J. B. (1998). The complete sequence of the 
locus of enterocyte effacement (LEE) from enteropathogenic Escherichia coli E2348/69. Molecular microbiology, 28(1), 1-4.

Igra, V., \& Irwin, C. E. (1996). Theories of adolescent risk-taking behavior. In Handbook of adolescent health risk behavior (pp. 3551). Springer, Boston, MA.

Kuther, T. L., \& Higgins-D'Alessandro, A. N. N. (2000). Bridging the gap between moral reasoning and adolescent engagement in risky behavior. Journal of Adolescence, 23(4), 409-422.

Kauffman, H., \& Hallahan, D. P. (1988). Exceptional children: Introduction to special education. Translated by Javadian $M$, Akhlaghi H and Saliani A, 2.p250.

Matarazzo, O., Abbamonte, L., \& Nigro, G. (2008, August). Moral reasoning and behaviour in adulthood. In Proceedings of world Academy of Science Engineering and Technology (Vol. 34, pp. 2070-3740).

McColgan, E. B., Rest, J. R., \& Pruitt, D. B. (1983). Moral judgment and antisocial behavior in early adolescence. Journal of applied developmental psychology, 4(2), 189-199.

Myyry, L. (2003). Components of morality: A professional ethics perspective on moral motivation, moral sensitivity, moral reasoning and related constructs among university students.

Perdices, M. (2018). Null Hypothesis Significance Testing, p-values, Effects Sizes and Confidence Intervals. Brain Impairment, 19(1).

Piaget,J.(1932).The moral judgment of the child .New York ;free press.

Pervin, L. A. (1994). A critical analysis of current trait theory. Psychological Inquiry, 5(2), 103-113. 
Refaat, A. (2004). Practice and awareness of health risk behaviour among Egyptian university students. EMHJ-Eastern Mediterranean Health Journal, 10 (1-2), 72-81, 2004.

Rest, J. R. (Ed.). (1994). Moral development in the professions: Psychology and applied ethics. Psychology Press.

Rest, J. R., Thoma, S. J., \& Bebeau, M. J. (1999). Postconventional moral thinking: A neo-Kohlbergian approach. Psychology Press.

Romer, D., Reyna, V. F., \& Satterthwaite, T. D. (2017). Beyond stereotypes of adolescent risk taking: Placing the adolescent brain in developmental context. Developmental cognitive neuroscience, 27, 19-34.

Rest,J.R.(1983).Morality . In :J.H.Flavell \&E.M.Markman (Eds.)Handbook of child psychology, vol.111 cognitive development, $4^{\text {th }}$ edition .New York ;John Willy ,pp.556-629.

Stoeber, J., \& Yang, H. (2016). Moral perfectionism and moral values, virtues, and judgments: Further investigations. Personality and Individual Differences, 88, 6-11.

Teng, Z., Nie, Q., Guo, C., \& Liu, Y. (2017). Violent video game exposure and moral disengagement in early adolescence: The moderating effect of moral identity. Computers in Human Behavior, 77, 5462. 